Chapman University

Chapman University Digital Commons

\title{
The Cultural Transmission of Trust Norms: Evidence from a Lab in the Field on a Natural Experiment
}

Jared Rubin

Chapman University, jrubin@chapman.edu

\section{Elira Karaja}

World Bank

Follow this and additional works at: https://digitalcommons.chapman.edu/esi_working_papers

Part of the Econometrics Commons, Economic Theory Commons, and the Other Economics Commons

\section{Recommended Citation}

Rubin, J., \& Karaja, E. (2017). The cultural transmission of trust norms: Evidence from a lab in the field on a natural experiment. ESI Working Papers 17-08. Retrieved from https://digitalcommons.chapman.edu/ esi_working_papers/218/

This Article is brought to you for free and open access by the Economic Science Institute at Chapman University Digital Commons. It has been accepted for inclusion in ESI Working Papers by an authorized administrator of Chapman University Digital Commons. For more information, please contact laughtin@chapman.edu. 


\section{The Cultural Transmission of Trust Norms: Evidence from a Lab in the Field on a Natural Experiment}

\section{Comments}

Working Paper 17-08

This paper later underwent peer review and was published as:

Rubin, J., \& Karaja, E. (2021). The cultural transmission of trust norms: Evidence from a lab in the field on a natural experiment. Journal of Comparative Economics. https://doi.org/10.1016/j.jce.2021.07.003 


\title{
The Cultural Transmission of Trust Norms: Evidence from a Lab in the Field on a Natural Experiment*
}

\author{
Jared Rubin ${ }^{\dagger}$ \\ Elira Karaja ${ }^{\ddagger}$
}

June 2018

\begin{abstract}
We conduct trust games in three villages in a northeastern Romanian commune. From 1775-1919, these villages were arbitrarily assigned to opposite sides of the Austrian and Ottoman/Russian border despite being located seven kilometers apart. All three villages were ruled by outsiders to Romania, with Russian and Ottoman fiscal institutions being more rapacious. We conjecture that this history, combined with historical selective migration, contributed to a culture of trust of outsiders (relative to co-villagers) on the Austrian side of the border. Our design permits us to test this conjecture, and more generally, whether historically-derived cultural norms are transmitted intergenerationally. We find that participants on the Austrian side that also have family roots in the village are indeed more likely to trust outsiders but less likely to trust co-villagers.
\end{abstract}

Keywords: trust, outgroup trust, trust game, culture, cultural transmission, natural experiment, field experiment, laboratory experiment, norms, Romania, Austria, Ottoman Empire, Habsburg Empire

JEL codes: C91, C93, N33, O17, Z1

\footnotetext{
${ }^{*}$ We are extremely grateful for excellent fieldwork conducted by Cult Market Research, led by Alexandru Zodieru, Paul Acatrini, and Alexandra Vijeu, and for research assistance performed by Cristian Anghel. We received insightful comments from Ran Abramitzky, Melissa Dell, Avner Greif, Karla Hoff, Saumitra Jha, Asim Khwaja, Timur Kuran, Avital Livny, Kaivan Munshi, Tom Pepinsky, Melina Platas, Bogdan State, and participants at workshops at Stanford, UC Irvine, the 2017 AALIMS Conference (Pomona), and the 2017 ASREC Conference. Funding from this project was generously provided by a grant Rubin received from the John Templeton Foundation. The experiment was approved by the Chapman University IRB, project number 1516H133. All errors are ours.

†Chapman University; email: jrubin@chapman.edu; Corresponding Author

${ }^{\ddagger}$ Harriman Institute at Columbia University; email: elirakaraja@gmail.com
} 


\section{Introduction}

Although it may seem obvious to a casual observer that "culture matters" for economic and political decisionmaking, it is not so obvious how it matters. How do we distinguish between cultural stimuli and economic, political, or institutional stimuli? To what degree do these stimuli feed into each other? Indeed, how do we even begin to quantify culture? The difficulty in providing satisfactory answers to these questions long dissuaded social scientists from investigating the connection between culture and political/economic outcomes, eschewing it as either untestable or unimportant.

However, culture has received a much revived interest from social scientists in the last two decades. While the term "culture" can mean many things, this literature generally conceptualizes culture as distinct from economic and institutional stimuli by defining it as the heuristics employed by people within a society to interpret the complex world around them (Boyd and Richerson 1985; Henrich et al. 2001; Wedeen 2002; Nunn 2012; Mokyr 2016; Greif and Mokyr 2016; Alston et al. 2016; Roland 2017; Giuliano and Nunn 2017). ${ }^{1}$ Within economics and political science, the causes and consequences of trust have received special attention. Trust is crucial to economic and political development (Arrow 1972; Putnam 1993; Whiteley 2000; Uslaner and Brown 2005; Karlan et al. 2009; Tabellini 2010; Algan and Cahuc 2010, 2013; Butler et al. 2016), and those heuristics that people use to determine whether or not to trust others and under which conditions to trust others clearly differ by society (Henrich et al. 2001). There are also practical reasons social scientists have recently focused on trust: there are numerous measures of trust collected in survey data (Fisman and Khanna 1999; Zak and Knack 2001; Alesina and La Ferrara 2002; Bahry et al. 2005; Hooghe et al. 2009; Aghion et al. 2010; Durante 2010; Nunn and Wantchekon 2011; Kasara 2013; Becker et al. 2016); and trust experiments are among the most widely used in experimental studies, both in the lab and in the field (Berg et al. 1995; Glaeser et al. 2000; Fershtman and Gneezy 2001; Fehr et al. 2002; Barr 2003; Karlan 2005; Sutter and Kocher 2007; Sapienza et al. 2013; Robinson 2016).

The most difficult issue the literature faces is one of identification: how do we know when a determinant is "culture" and when it is some (potentially unobservable or institutional) variable related to culture? Convincing identification strategies used to separate cultural determinants from other economic, political,

\footnotetext{
${ }^{1}$ Following from important works such as Putnam (1993) and Greif $(1994,2006)$, the recent literature seeks historical channels through which distinct cultural attributes formed and still affect decision-making heuristics in the present. For instance, Guiso et al. (2016) subject Putnam's hypothesis to a rigorous empirical test, showing that differences in medieval institutions and the resulting social capital differences had an impact in northern Italy but not in southern Italy. Greif's work falls into a much broader literature which views institutions as the carriers of carriers of the historical —and hence cultural—past. Also see North (1990), David (1994), Engerman and Sokoloff (1997), La Porta et al. (1998), Acemoglu et al. (2001), Tabellini (2008a), Dell (2010), Voigtlaender and Voth (2012), Alesina et al. (2013), Jha (2013), Gorodnichenko and Roland (2017), Greif and Tabellini (2017), and Dell and Olken (2017). For excellent overviews of recent developments in the culture and institutions literature, see Guiso et al. (2006), Nunn (2012), and Alesina and Giuliano (2015). For important overviews of recent works on the cultural transmission of traits and its effect on long run economic development, see Spolaore and Wacziarg (2013) and Gershman (2017). Of particular relevance to the current paper is Algan and Cahuc (2013), who provide a nice review of the literature on trust and economic outcomes, and Nannestad (2008), who overviews the literature on generalized trust.
} 
sociological, or institutional determinants have included instrumental variables (Uslaner and Brown 2005; Tabellini 2010; Nunn and Wantchekon 2011), regression discontinuity (Grosfeld et al. 2013; Grosfeld and Zhuravskaya 2013; Karaja 2013; Becker et al. 2016; Buggle 2016), and laboratory or field experiments (Fershtman and Gneezy 2001; Cassar et al. 2013; Adida et al. 2016; Bigoni et al. 2016; Butler et al. 2016; Robinson 2016; Lowes et al. 2017; Jeon et al. 2017). ${ }^{2}$ Yet, there are tradeoffs inherent in each of these approaches. Instrumental variables are excellent at removing the bias from the regression coefficients in question and counteracting omitted variable biases inherent in historical data, but they often cannot provide much additional insight into the pathway through which culture is transmitted and affects outcomes. ${ }^{3}$ Regression discontinuity analyses address this concern — so long as there are not multiple important causal implications of the discontinuity in question - but they come with the tradeoff that discontinuities are frequently not completely exogenous. Long borders, the most commonly used feature over which regression discontinuity analyses are employed, are rarely random along the entirety of the border; they are often formed by geographical barriers, the commercial importance of the region, and the capacity of the center to collect taxes from either side of the border. ${ }^{4}$ Finally, most experiments seeking to understand how people with different cultural backgrounds behave in different environments do indeed shed significant light on how people act - often in contradiction to conventional economic theory-but they have difficulty isolating the cultural determinants of subjects' actions. ${ }^{5}$

Our paper aims to address some of these tradeoffs by combining a "lab in the field" experiment with a natural experiment. ${ }^{6}$ The idea is straight-forward: if one can find a natural experiment in which a historical border was arbitrarily drawn, even if over a small expanse, and there is reason to believe that there are historical mechanisms on either side of the border affecting culture, one can more finely pinpoint the degree

\footnotetext{
${ }^{2}$ Some papers have also exploited historical patterns that are likely only explicable through culture. For instance, Gangadharan et al. (2017) run lab in the field experiments in Cambodia, showing that participants who were directly affected by the Khmer Rouge genocide exhibit more anti-social behavior in the present. Algan and Cahuc (2010) exploit variation in immigration patterns to the US to isolate the inherited component of trust and test its impact on economic outcomes. Giuliano (2007) also exploits immigration patterns to the US to isolate cultural differences between southern and northern Europeans with respect to how long children live with their parents. Giuliano's findings suggest that culture accounts for several stylized facts that purely social scientific explanations cannot account for. More insight into inter-generational cultural transmission is provided by Giuliano and Nunn (2017), who find that groups whose ancestors lived in more stable environments place a greater emphasis on maintaining tradition in the present.

${ }^{3} \mathrm{~A}$ large theoretical literature addresses the mechanisms through which cultural transmission occurs. Bisin and Verdier (2001), Tabellini (2008b), and Guiso et al. (2008) focus primarily on the intra-family transmission process, while Dohman et al. (2012) highlight the role of assortative mating and the local environment. Bisin and Verdier (2017), Kimbrough et al. (2008), Greif and Tadelis (2010), and Iyigun and Rubin (2017) provide arguments for how culture and institutions interact.

${ }^{4}$ While one can run a test for pre-existing differences on either side of the discontinuity (e.g., Becker et al. 2016), such data from the pre-existing period are often much worse due to their historical nature and are subject to omitted variable bias. One example of a set of long, exogenous borders are those created in the "scramble for Africa". The borders were created in a European board room with little concern for ethnic or geographical boundaries (Michalopoulos and Papaioannou 2016).

${ }^{5}$ For instance, if subjects from northern and southern Italy act differently in trust games (Bigoni et al. 2016), it is possible that this is due to differences in social capital between the two regions (Putnam 1993) or some other cultural factor; and there are many other differences between the two regions which are difficult to account for in an experimental setting.

${ }^{6}$ For a recent survey of the "lab in the field" literature, with all its benefits and pitfalls, see Gneezy and Imas (2016). A similar "lab in the field on a natural experiment" method is used to provide insight into public good provision in India (Chaudhary et al. 2017).
} 
to which cultural differences persisted by running laboratory experiments on subjects on either side of the border. The primary challenges of such an undertaking are: i) finding an arbitrarily drawn border - as noted above, most long borders are not arbitrary; ii) finding a border in which there is reason to believe there were cultural differences generated by the border; and iii) isolating the border effects from other economic determinants which may also be different on either side of the border.

We address these challenges by running trust games on either side of an old Austrian (Habsburg) border in the Udeşti Commune located in northeastern Romania. This commune provides an ideal setting for testing the role that historically-generated cultural differences played in generating modern-day trust behavior for four reasons. First, a "natural experiment" occurred within the commune after it was annexed by the Austrians following the Treaty of Küçük Kaynarca in 1774, in which the Ottomans ceded the Bukovina region of Moldavia to the Austrians (see Figure 1). One of the villages in the commune, Ştirbăt, was left on the Ottoman side despite there being a more natural river border to the north of Ştirbăt (see Figure 2). Historical records indicate that this decision was due in large part to the idiosyncratic predilections of one landowner in Ştirbăt, not some economic or geographical calculus. This "natural experiment" therefore satisfies the arbitrariness criterion. The border was not created by economic, military, or even geographical considerations, but was the result of the idiosyncratic desires of one individual over two centuries ago.

Second, a large literature suggests that the decentralized, efficient, and (relatively) corruption-free Austrian administration fostered trust in government (Becker et al. 2016; Karaja 2013; Dimitrova-Grajzl 2007; Subtelny 2007; Grosfeld and Zhuravskaya 2013), while the Ottoman administrative system known as the malikane system was rapacious (İnalcık 1973; Coşgel et al. 2013). This helped contribute to a relative paucity of trust in the former Ottoman lands (Dimitrova-Grajzl 2007; Karaja 2013). Although Moldavia (i.e., the region containing Ştirbăt) entered the Russian sphere of influence in 1829, Russian administration was similarly rapacious (Subtelny 2007; Grosfeld and Zhuravskaya 2013). Since all three of these empires were outsiders to Romania, we conjecture that these histories should have affected the "cultural lens" through which individuals on either side of the border trusted outsiders more generally. In other words, our experiment is designed to test whether people from villages that were "treated" with Austrian rule (as opposed to Ottoman rule, which had existed in the region since the 15th century) trust outsiders more than those that were not treated. Moreover, there is evidence of selective migration into (non-Austrian) Ştirbăt in the late 18th century. The first settlers were either forced to settle (as part of Madame Ştirbeţ's corvée) or migrated due to dislike of their new Austrian overlords. Importantly, both of these phenomena - administrative differences and selective migration - suggest that a culture of relative "trust of outsiders" may have emerged in the late 18th and 19th centuries on the Austrian side of the border. ${ }^{7}$ The historical border therefore

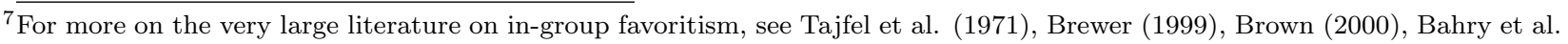


Figure 1: The Austrian-Ottoman Border in the Late-18th Century

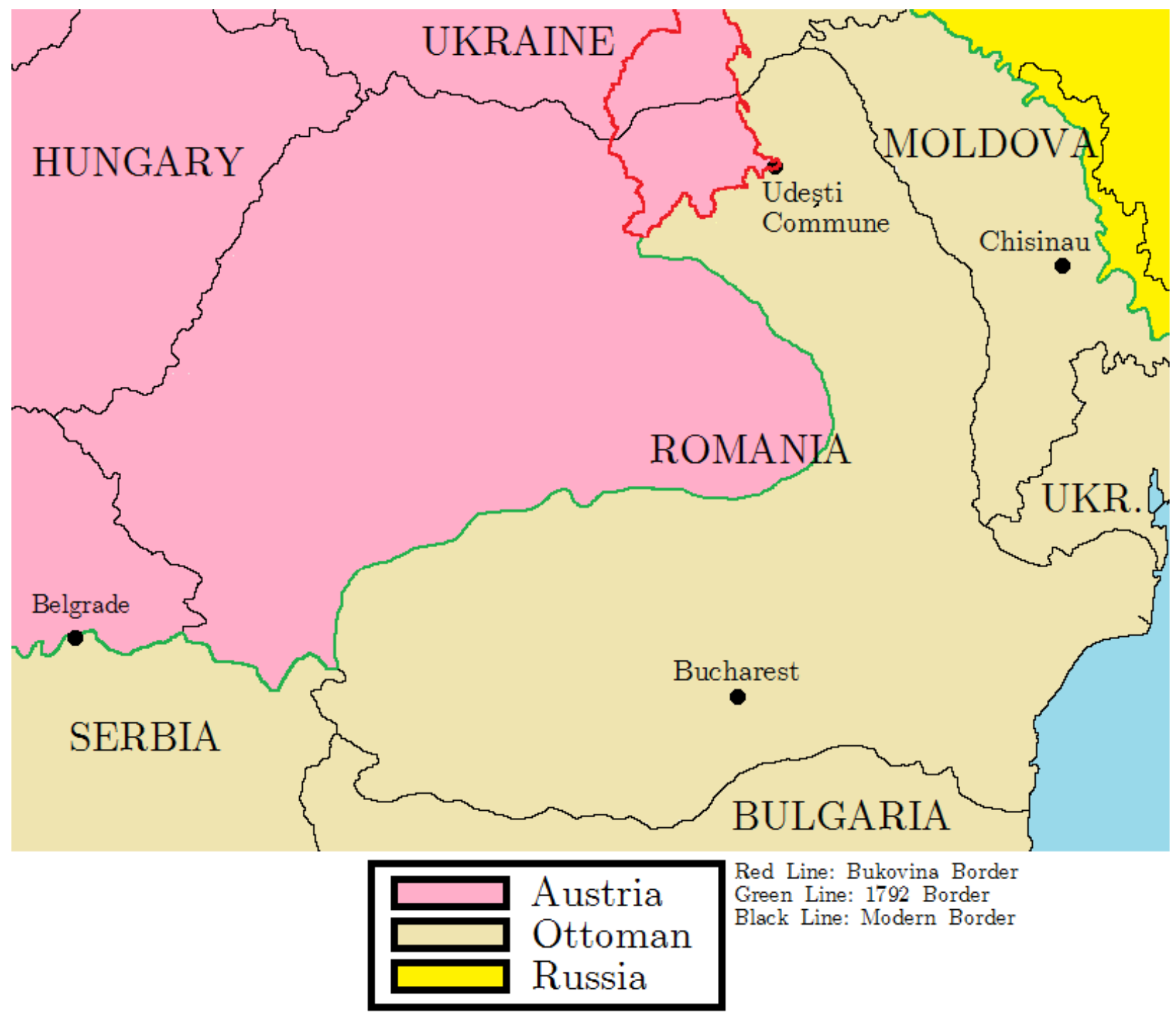

satisfies the cultural difference criterion. There is reason to believe that cultural differences were generated by historical events on other side of the border and are not merely associated with the border for spurious reasons.

Third, the commune was reunified in 1919, meaning that for nearly a century the commune has shared common governance, fiscal institutions, communist legacies, and many other features one might expect would affect contemporary trust. The natural experiment therefore satisfies the historical channel criterion. PostWorld War I economic and political events cannot explain differences between the villages, since they have been subject to the same forces for nearly a century. While it is likely true that political and economic (2005), Yuki et al. (2005), Tanis and Postmes (2005), Ruffle and Sosis (2006), Balliet, Wu, and de Dreu (2014), and Robinson (2016). 
Figure 2: Udeşti, Poieni, and Ştirbăt Villages

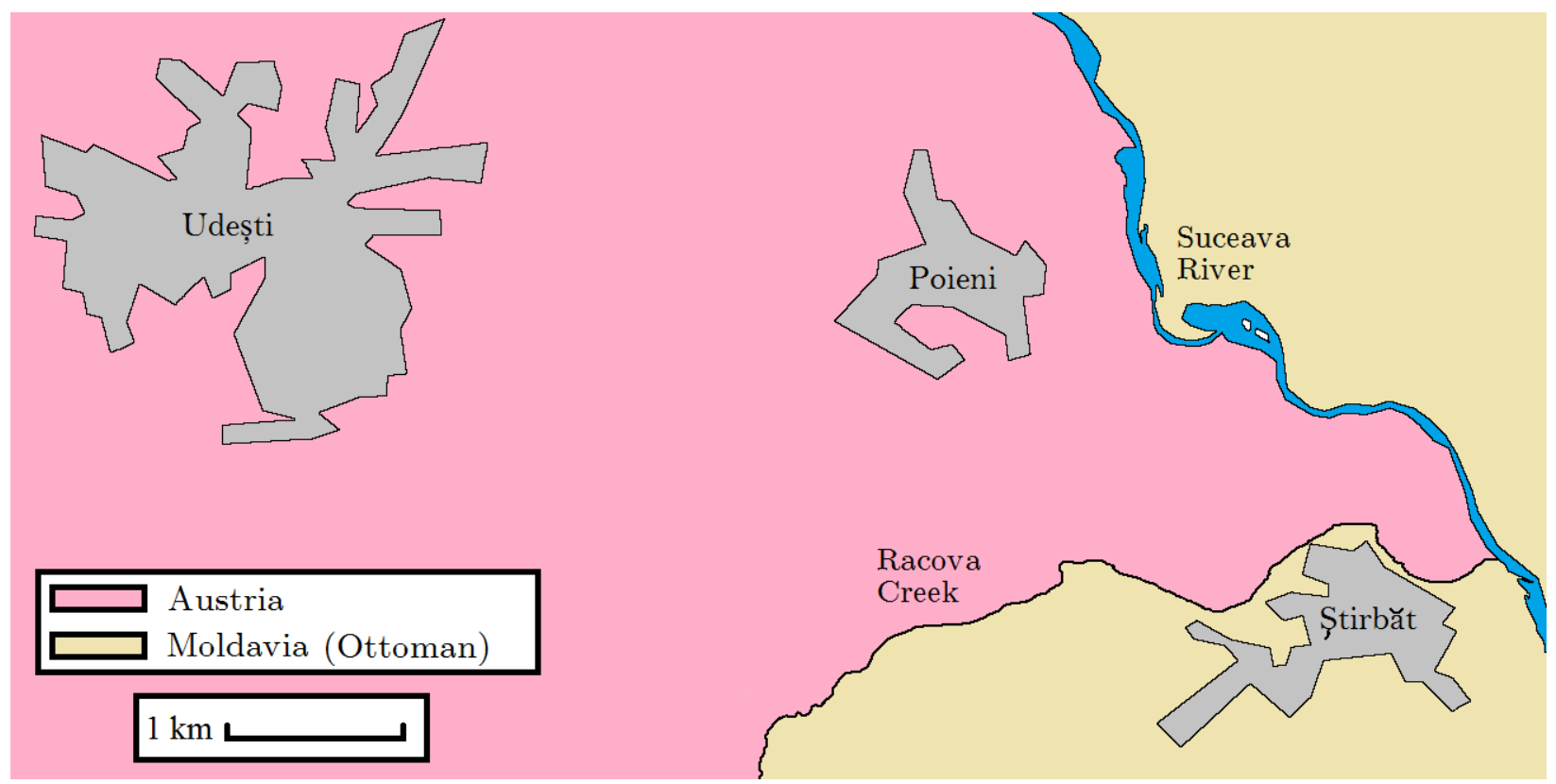

differences persist in general on either side of the old Austrian-Ottoman border, one of the advantages of our methodology is that the three villages under study are small enough that any such differences would have been unlikely to survive the Communist period, in which the villages were placed under the same communal leadership. Hence, if differences in trust across villages are found, especially if they are in the expected direction, cultural differences generated by the historical border are a plausible root cause.

Finally, our experiment allows us to parse whether those whose families have lived in the villages for multiple generations - and were thus presumably more imbued with the culture of their ancestors - exhibit different trust behavior than those who are relative newcomers. Ancestral information was obtained in a post-experiment survey. Should such differences arise, they would provide further evidence that the intergenerational transmission of culture underlies our results rather than some unobserved differences between the villages.

The experimental design entails playing trust games in two villages on the Austrian side of the border (Udeşti and Poieni) ${ }^{8}$ and one on the Ottoman/Russian (hence, non-Austrian) side (Ştirbăt). Figure 2 depicts just how close these villages are to each other; each is within walking distance of the other two villages. Ideally we would have run trust games in a second village on the non-Austrian side, but Ştirbăt is the only village in the commune that satisfies this criterion. Participants in all villages played trust games with both co-villagers and people from one of the other villages (hence, outsiders). Our "treated" group is

\footnotetext{
${ }^{8}$ Udeşti is the name of both the commune as well as a village in the commune. To avoid confusion, we refer to the former as the "Udeşti Commune" throughout the paper.
} 
therefore those whose villages were treated with Austrian institutions (Udeşti and Poieni), while our control group is those whose village was not (Ştirbăt). We also analyze actions between the two treated (Austrian) villages, under the hypothesis that there should be no differences, on average, in actions between the two.

Our findings support the conjecture that historically-induced culture affects contemporary trust and that inter-generational transmission is a plausible mechanism. First, we find that participants on the treated (Austrian) side of the border have greater trust of subjects from outside their village (i.e., they send more tokens). Meanwhile, no (significant) differences in trust behavior are found between the two treated villages. Second, we find that these inter-village differences in trust of outsiders only arise for subjects whose grandparents are from the village in question. We interpret this result as evidence of an inter-generational transmission mechanism; it is only those subjects whose families experienced the institutional differences of 1774-1919 - or, at the very least, subjects whose grandparents grew up with people that experienced these differences - that showed differences in trust of outsiders. ${ }^{9}$

We do not wish to over-interpret our results for three reasons. First, these findings will be difficult, if not impossible, to replicate. In such small villages, one would be worried about playing the same game twice. Second, in one respect we identify cultural differences off of three village-level observations. In such a micro-level study, it is possible that some unknown, benign event in one of the villages' historical past is responsible for our results. Third, the external validity of our methodology is not obvious. Such issues are not faced with larger-N studies that employ IV or regression discontinuity to identify cultural differences. For this reason, we do not advocate that a "low-N" study like ours be the first attempt at identifying cultural persistence across different populations. Instead, we suggest that such studies be done in conjunction with other high-N studies employing some other technique to address identification. In the specific historical case we study, such studies have been undertaken (Dimitrova-Grajzl 2007; Karaja 2013; Becker et al. 2016), supporting the external validity of our results. Hence, since our study addresses precisely the primary tradeoffs faced by other methodologies used to address cultural persistence, the present study should be viewed as complementary to existing studies. Indeed, the fact that our results are consistent with much of the literature cited above lends credibility to both sets of results.

The paper proceeds as follows. Section 2 overviews the relevant historical facts of the villages in which we conduct the experiment. Section 3 summarizes the experimental procedure. Section 4 informally maps out a theory, based on the literature, of what we should expect to see in the experiment if the cultural transmission of trust norms is indeed salient. Section 5 reports the results, and Section 6 concludes.

\footnotetext{
9 Vertical cultural transmission cannot account for all of our results. Among participants whose grandparents are not from the village, those from the Austrian side of the border trust co-villagers less than those from the non-Austrian side. We consider explanations for these results in Section 5 .
} 


\section{Historical Background: The Udeşti Commune}

\subsection{Austrian, Ottoman, and Russian Administration}

There were numerous institutional differences between the Austrian Habsburg Empire and its two eastern neighbors, the Ottoman Empire and Russian Empire, which may affect contemporary trust. Perhaps the most important Austrian institutional feature for the present study was the relative autonomy of local governance (including in Romania, as we highlight in the next section). The Habsburgs had long permitted (though perhaps not desired) strong free independent cities, which were independent centers of political, economic, and cultural activity. Administrative and cultural autonomy was also the norm in the more peripheral Austrian territories, where locals manned the bureaucracy and were permitted wide purview over economic, religious, and cultural matters (Subtelny 2007; Grosfeld and Zhuravskaya 2013). Indeed, there is a large literature, summarized by Becker et al. (2016), suggesting that the Austrian bureaucracy was known for its honesty, diligence, fairness, efficiency, and freedom from corruption. When the Habsburgs acquired new territories, locals were sent to Vienna for extensive administrative training before returning to work in the bureaucracy. As a result, the Austrian bureaucracy was largely respected by the population, even in newly acquired territories where the Austrians were ostensibly "outsiders" (Becker et al. 2016).

In contrast, the Russians rarely compromised on their autocratic prerogatives or gave political power to local elites. Local elites were given socio-economic privileges in order to ensure their subservience to the tsar, who imposed oppressive cultural, social, and economic policies on regions that were not fully integrated or assimilated into the empire (Subtelny 2007; Grosfeld and Zhuravskaya 2013). As a result, there were few local power bases outside of the central government, and the ties between local elites and the masses were much weaker than they were in the Habsburg lands (Subtelny 2007). In other words, the relatively rapacious elites in Russian governance would have been viewed as outsiders, especially in peripheral territories like Romania. Meanwhile, the Ottoman political structure became decentralized after the 17th century, as local notables acquired control over most local political and economic affairs (İnalcık 1973; Barkey 1994; Coşgel et al. 2013). But unlike the Austrian regime, which maintained a tight relationship with the local nobility and therefore maintained some level of control over corruption, Ottoman decentralization was a result of the center's inability to collect revenue or provide local law and order. The Ottoman central authorities could do little to prevent corruption and expropriation. ${ }^{10}$

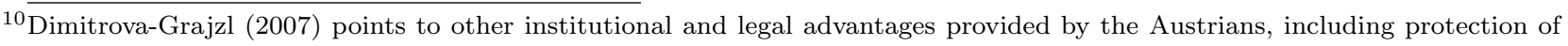
property rights, relative freedom from corruption, autonomy for local governance, and provision of public goods. With respect to property rights, the Austrians permitted private ownership as early as the 17th century, abolished serfdom in the late 18th century, increased peasants' rights, ended censorship, and ensured freedom of enterprise in 1859. Meanwhile, the Ottomans did not permit private ownership until the 19th century (all land belonged to the Sultan) and permitted local military lords to take arbitrary levies and surcharges, resulting in massive extortion and oppression of the masses, especially in the southeastern European Ottoman provinces. The deteriorating Ottoman fiscal situation encouraged predatory behavior on the part of tax 
In short, the institutional differences between the Austrian, Ottoman, and Russian Empires relevant for this study are autonomy of local governance, freedom from corruption, and protection of property rights. A growing literature suggests that these differences helped shape cultural attitudes that have persisted to the present day. Becker et al. (2016) employ a regression discontinuity around the old Habsburg border and find that Habsburg affiliation increases trust with respect to government institutions and reduces corruption (i.e., bribery) in contemporary courts and police. They argue that norms of functional citizen-state interactions, along with a decentralized and honest bureaucracy, affected trust in local public services and levels of corruption in local administration. Karaja (2013) uses a similar design across the old Austrian-Ottoman border and finds higher willingness to bribe, lower trust of public officials, and lower growth in GDP per capita in the old Ottoman lands. Dimitrova-Grajzl (2007) uses a variety of econometric techniques and finds that Habsburg successor states have more efficient market economies, greater protection of property rights, lower risk of government exploitation of private investors, lower levels of corruption, higher trust in the government, greater governmental effectiveness, and stronger civil society than Ottoman successor states. These outcomes can all be explained by the differences in Austrian and Ottoman institutions highlighted in this section. Grosfeld and Zhuravskaya (2013) find that within Poland, Habsburg and Russian legacies affect contemporary voting patterns, with people in former Habsburg lands being more likely to vote for both liberals and religious conservatives. They cite Austrian local autonomy, especially with regard to religious issues, as the reason for support of religious conservatives, while differences in governance institutions affected beliefs in democracy on both sides of the border and thus support for liberals. ${ }^{11}$

This literature therefore suggests that Austrian, Ottoman, and Russian institutional differences may still affect a host of economic, cultural, and political features generally considered important for economic development. Foremost among these is trust. Although the literature focuses on trust in government, we conjecture that the fact that these empires were "outsiders" in Romania, in combination with the manner in which the empires administered local governance, should have manifested itself in trust of "outsiders" more generally. Austrian officials were "insiders" - local elites who became steeped in Austrian bureaucratic practices. Meanwhile, Ottoman and Russian government officials would have been outsiders to a vast majority of their subjects. Their widespread corruption and imposition on property rights decreased trust in public officials, and likely decreased trust in outsiders more generally.

A large experimental literature suggests that "outgroup" trust is in part culturally determined (Tajfel et al. 1971; Brewer 1999; Brown 2000; Bahry et al. 2005; Yuki et al. 2005; Tanis and Postmes 2005; Ruffle and

farmers - illegal taxes and land reallocation were common - and the sultan was hesitant to intervene since this may have worsened his fiscal straits (Coşgel et al. 2013; Karaja 2013).

${ }^{11}$ In a related study, Grosjean (2011) finds that Ottoman rule is associated with lower contemporary financial development, even within countries that were partially ruled by the Ottoman Empire. 
Sosis 2006; Robinson 2016), although it can also be generated in the lab (Chen and Li 2009). ${ }^{12}$ The Austrian, Ottoman, and Russian institutional legacies therefore suggest the possibility - should the cultural differences generated by these institutions over a century ago be sticky enough to exist in the present- that outgroup trust should be greater for descendants of the Austrian Empire. In Section 4, we more formally lay out this and other predictions related to differences in trust between those from the Austrian and non-Austrian sides of the old border. Before we provide the intuition underlying these hypotheses, we provide the historical background of the natural experiment in Romania that we exploit (in Section 2.2) and summarize the game that participants on both sides of the border played (in Section 3).

\subsection{The Udeşti Commune: A Brief History}

The Udeşti Commune is located in the Moldavian region (Suceava County) of northeastern Romania. ${ }^{13}$ It is comprised of 11 small villages over approximately $11.04 \mathrm{~km}^{2}$ (Udişteanu 2005), ranging from the very small (Mănăstioara, which has 23 households), to the largest village Udeşti, which has approximately 1,100 households. There is evidence of human inhabitance of Udeşti from the Paleolithic and Neolithic eras, and there has been permanent settlement since at least the late medieval period (Marţolea 1986). The largest of the villages in terms of population and size, Udeşti, was formed no later than the 1580s; it was originally a settlement for corvée workers of the royal court and other high officials (Marţolea 1986, p. 35).

Prior to 1775, the entire Udeşti Commune was part of the Bukovina region of Moldavia, a region which spans parts of modern day Romania, Moldova, and Ukraine. Moldavia fell under indirect Ottoman control in 1454, although it retained a degree of independence (Inalcik 1973, p. 27). Like other Christian vassal principalities of the Ottoman Empire (e.g., Wallachia, Transylvania, Dubrovnik, Georgia, and Circassia), Moldavia was ruled by its own princes as an Ottoman vassal state.

The major event in Udeşti history that we exploit in this paper is the partition following the signing of the Treaty of Küçük Kaynarca. Under the terms of this treaty, which ended the Russo-Turkish War in 1774, the Ottoman Empire ceded Bukovina to the Austrian Habsburg Empire (Udişteanu 2005). ${ }^{14}$ As can be seen in Figures 1 and 2, the Udeşti Commune is located on the border of Bukovina and what would remain Ottoman Moldavia. The citizens of Bukovina, including those in the Udeşti Commune, were required to take an oath in 1777 to their new Austrian empress Maria Theresa. ${ }^{15}$

${ }^{12}$ The "ingroup favoritism" literature is a large and old one in psychology and sociology. Ruffle and Sosis (2006) note that "hundreds of in-group-out-group bias studies fill psychology and sociology journals." Indeed, this literature is large enough to have warranted a meta-analysis; see Balliet, Wu, and De Dreu (2014).

${ }^{13}$ The Udeşti Commune was not a commune until the 20th century, but we use this terminology to describe the entire area, as opposed to the individual village of Udeşti.

${ }^{14}$ The terms of the treaty permitted the Russian Empire to intercede when necessary on behalf of Eastern Orthodox Christians living in Moldavia.

${ }^{15}$ The "Oath of Faith to Austria" indicated Austria's interest in Bukovinan tax revenue, which required legal, judicial, and administrative apparatuses: "I, Maria Terezia, widow and sovereign empress of the Hungarian Land and of Bukovina, etc. ... 
However, not all Udeşti residents were willing to live under Austrian rule. In 1777, one of the major landowners in the village, Ruxanda Ştirbeţ, was called to submit an oath in the name of her village, Chilişeni, to the new Austrian rulers (Chilişeni is located on the west bank of the Racova Creek, see Figure 2). Ştirbeţ refused to participate in the ceremony, which she considered "to be despotic and a crippling of Moldavia" (Marţolea 1986, p. 13). Afterwards, Ştirbeţ left her house in Chilişeni and moved to a nearly-unoccupied parcel of land on the opposite side of the creek, which at the time was still part of Chilişeni. ${ }^{16}$ Ştirbet claimed that this heretofore unproductive land was still part of Moldavian territory. When brought up before the before the Austrian Inventory Commission on December 13, 1782, Ştirbet argued that "the largest part of Chilişeni Village is in Moldavia and [SStirbeţ] owns all the estate." (Marţolea 1986, p. 12). Being nearly uninhabited prior to Ştirbeţ's move, there is no evidence one way or the other that it would have been considered part of Bukovina (and thus ceded to the Austrians) prior to the Treaty of Küçük Kaynarca. In 1786, the Austrians recognized Ştirbeţ's claim and set a border stone on the right bank of Racova Creek, between Chilişeni and Ştirbeţ's new settlement, which would later bear her name, Ştirbăt. The Austrians also placed a border station on the left side of the bank, clearly demarcating Austrian from Moldavian (Ottoman) territory (Marţolea 1986, p. 13).

Soon after Ştirbăt was formed, its population grew as families from Bucovina, Transylvania, and Maramures, many of whom viewed themselves as Moldavian, escaped foreign occupation. Some were chased by Austrian authorities and compelled to return to their lands; others refused and stayed in Ştirbăt. In short, the initial population was comprised mostly of Madame Ştirbeţ's corvée and selectively chosen migrants. ${ }^{17}$ These migrants tended to be good farmers and animal breeders, and they shortly blended in with the local population, eventually gaining the right to own their own land. By 1828, there were 43 households in Ştirbăt, and the Moldavian Treasury in 1845 showed 51 households (Marţolea 1986, p. 15). Most of the inhabitants were slaves or corvée workers until the formation of the United Principalities of Moldavia and Wallachia in 1859. In 1864, Prince Alexandru Ioan Cuza abolished slavery and made peasants landowners (Marţolea 1986, p. 53). This contrasts with Austrian Bukovina (i.e., Udeşti), where the Austrian government eliminated slavery on the commune immediately after taking control in 1775, issuing a decree permitting serfdom. Austrian Bukovinan peasants were required to provide 3-6 days a week of unpaid work for the masters of

approach every person who is an inhabitant of Bukovina Districts, who lives here, or who owns lands here, who is our servant, who pays tribute to us or who is worthy of our protection ... First of all we assure you of our imperial and royal mercy ... For this, we need no more than for the inhabitants of this district of Bukovina, both the religious and the laic ones and the common people who live here, to submit their oath and pledge to be our subjects, becoming our obedient taxpayers. Based on this oath, they pledge to uphold the justice and the order that we instate, agreeing for us to take care of them and always have faith in us and in the fact that we will always be just and correct with Bukovina district (quoted in Udişteanu 2005)."

${ }^{16}$ According to census taken in 1772-74, this small village, known as Lăţcanii, contained 9 households consisting of three families, a priest, and three poor women (Marţolea 1986, p. 14).

${ }^{17}$ Today, Ştirbăt still has numerous families whose names are from the Bucovina, Transylvania, and Maramures regions (Marţolea 1986, p. 14). 
the estate (Marţolea 1986, p. 51). These regulations were relieved in 1835, when a decree by the Emperor Ferdinand stated that all peasants' land was henceforth their private property.

The villages in the Udeşti Commune under Austrian control (including Udeşti and Poieni, two of the three villages in which we conduct the experiments) remained under Austrian rule until Romania established control over Bukovina in 1919, following the collapse of Austria-Hungary after World War I. Moldavia (including Ştirbăt) fell under various rulers following the Treaty of Küçük Kaynarca. Until the RussoTurkish War of 1828-29, it remained under both Ottoman and Russian spheres of influence. After the war, it fell under Russian domination for three decades until the conclusion of the Crimean War. As part of the Treaty of Paris (1856) in the aftermath of the Crimean War, Moldavia unified with Wallachia (to its south) to form the independent state known as The United Principalities of Moldavia and Wallachia. The United Principalities were the predecessor to the Kingdom of Romania (1881-1947), which eventually incorporated Bukovina in the Treaty of Saint Germain (1919). In 1947, the Kingdom of Romania was proclaimed the Socialist Republic of Romania, and it remained under one party Communist rule until 1989. In 1950, under the communist regime, the Udeşti Commune was organized as a commune managed by a Popular Council. On December 24, 1960, an administrative reform placed the Udeşti Commune within the Suceava District (Udişteanu 2005, ch. 1).

The upshots of this short history of the Udeşti Commune are: i) one village in the commune, Ştirbăt, fell under non-Austrian rule for 144 years (1775-1919), while the rest of the commune, including Udeşti and Poieni, fell under Austrian rule; ii) these differences were not the result of geography, military strategy, or any of the conventional causes of territorial boundaries, but the predilections of one landowner (Ruxanda Ştirbeţ); iii) part of the initial population of Ştirbăt was selectively chosen, as it consisted largely of people escaping Austrian rule for some reason or another; iv) the commune has been reunified for nearly a century (since 1919), and it has experienced a World War, an extended period under Communist rule, and the post-Communist era as one commune.

These features combine for an ideal natural experiment to test whether trust norms are transmitted over generations long after the cessation of the conditions under which those norms formed in the first place. First, the boundary within the commune between the Austrian and Moldavian side is about as exogenous as one could hope for, being generated primarily by the predilections of one landowner. Second, these villages fell under the rule of very different regimes which, as outlined in Section 2.1 and later more formally in Section 4, suggest the possibility that different trust norms were formed over two centuries ago between the villages. Third, to the extent that selection into non-Austrian Ştirbăt (and out of Austrian Udeşti and Poieni) existed in the late-18th century, such selection should affect trust in same direction as the institutional differences (i.e., residents of Ştirbăt should be less trusting of outsiders). As we discuss in greater detail in Section 4, 
this means that we must remain agnostic regarding the root cause of cultural differences (i.e., OttomanRussian-Austrian institutions or selective migration in the 18th century), but it does not undermine our focus on the persistence of cultural norms. Finally, the villages have been united under the same national and local governance for nearly a century, meaning that observed differences in trust behavior are not a result of different experiences with communism or any other post-World War I phenomenon.

For the sake of the experiment, we consider the Austrian side of the border (Udeşti and Poieni) to be "treated" with Austrian institutions from 1774-1919 and outmigration in the late 18th century. This is a "treatment" because, prior to 1774 , all of the villages in question had been under Ottoman rule for over two centuries. Hence, there was no change in the basic institutional structure of the control village (Ştirbăt) until at least 1859, when the United Principalities of Moldavia and Wallachia formed. Meanwhile, Austrian institutions prevailed in Udeşti and Poieni until 1919. In the following section, we detail the "lab in the field" experiment designed to exploit this natural experiment.

\section{A Lab in the Field on a Natural Experiment: Design and Im- plementation}

\subsection{Experiment Design and Instructions}

We designed a "lab in the field" experiment to exploit the natural experiment discussed in Section 2.2. Participants played simple trust games (as in Berg et al. 1995) in one village on the non-Austrian side of the border, Ştirbăt, and two villages on the Austrian side of the border, Udeşti and Poieni. Participants played simplified versions of trust games played hundreds of times in university laboratories.

Participants played the same trust game multiple times. In each game, they were first told the village of residence of the person they would be matched with. They were then told whether they would be a "sender" or "receiver", although these terms were not used (see Appendix B for instructions in English and Appendix C for instructions translated into Romanian). The exact identity of one's partner was not known; matches were randomly determined by a spreadsheet, so even the experimenters did not know the identity of the matched pairs. Participants were given an incentivized quiz before making their decisions in the first game in which they participated (see Appendix B.3).

The sender made one decision: how many of three tokens to send over to his or her partner. They made this decision by simply circling $0,1,2$, or 3 on a handout provided to them by an experimenter (see Figure 3). Participants were instructed that they would keep any tokens they did not send, while any tokens they sent would be multiplied by 3 and given to the receiver. Each token was equivalent to 3 Romanian lei, or 
$\$ 0.75$.

Figure 3: Handout Participants Filled Out to Make the Send Decision

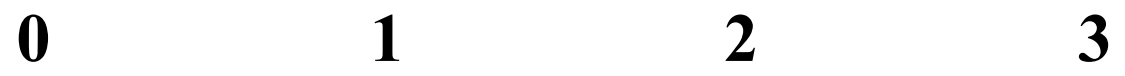

Circle one of the above numbers. The number you circle is the amount of your 3 tokens you will send to the participant with whom you are matched.

Please only circle one number. If you change your mind, cross out your choice and make a new choice.

Senders were then told that receivers would make a choice of how many of the tokens they received to return to the sender. Receivers made 3 decisions: how much to return to the sender conditional on the sender sending 1, 2, or 3 tokens (see Figure 4). If the sender sent 0 , there was nothing for the receiver to return, so we circled "0" for participants. For each of the three decisions, receivers were allowed to circle any number between 0 and three times the amount sent to them to return to the sender.

Figure 4: Handout Participants Filled Out to Make the Return Decision

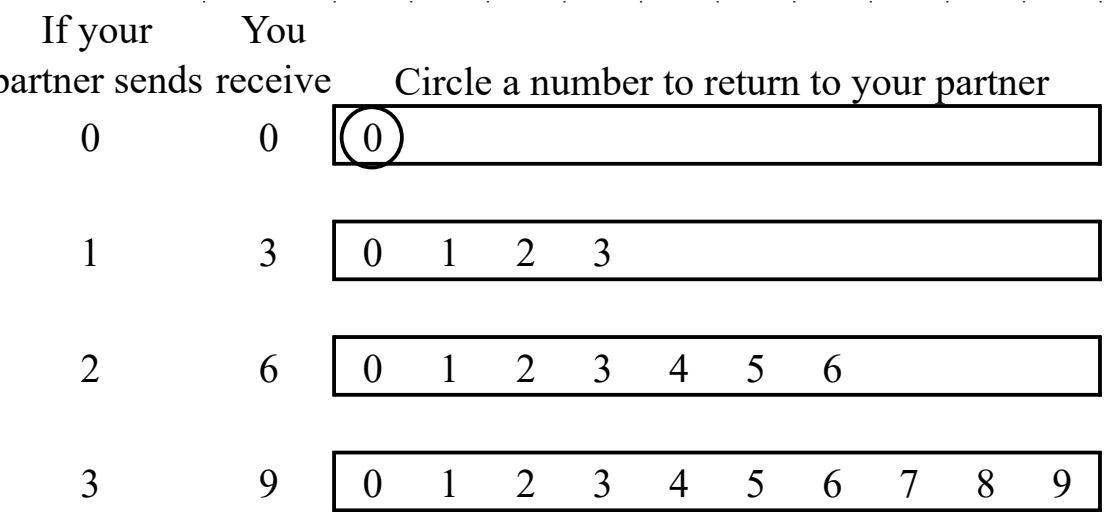

Participants first played the game as a sender, matched with a receiver from either their own or another village, and then played the game as a receiver, matched with a different sender from that village. All participants played the game at least four times (twice as a sender and twice as a receiver), matched with co-villagers and outsiders. Instructions were similar, although abbreviated, for receivers. After participants completed the final treatment they took a short demographic survey (see Appendix B.4 for details).

\subsection{Treated and Control Groups}

As of July 2016, there were around 1,100 households in (Austrian) Udeşti, 270 households in (Austrian) Poieni, and 300 households in (non-Austrian) Ştirbăt. Since Udeşti is over three times the size of the other 
two villages, we recruited more subjects from Udeşti. In all, there were 200 participants from Udeşti and 100 participants from both Poieni and Ştirbăt, equaling 400 total participants. Given the unequal numbers from each of the villages, we augmented the game slightly for participants from each of the villages in a manner described below.

As described in Section 2, the treated group includes the 300 participants from the Austrian side of the border (200 from Udeşti and 100 from Poieni). These villages were "treated" with Austrian institutions and outmigration in the late 18th century. Meanwhile, the control group includes the 100 participants from (non-Austrian) Ştirbăt. All participants played the game multiple times. In the first and third games they played as a sender and in the second and fourth games they played as a receiver. One hundred of the (Austrian) Udeşti participants played two games with people from Udeşti and the other two with people from (non-Austrian) Ştirbăt while the other 100 played twice with co-villagers and twice with people from (Austrian) Poieni. Meanwhile, both the 100 Poieni and 100 Ştirbăt participants played two games with people from all three villages (in the fifth game they acted as sender and in the sixth as receiver, playing with outgroup participants). To control for order effects, we split each of these groups into two, alternating the order of game play. For a summary of the order of play see Table 1.

Table 1: Order of Play in the Treated and Control Groups

\begin{tabular}{|c|c|c|c|}
\hline Village & Side of Border & Order & $\mathrm{N}$ \\
\hline \multicolumn{4}{|c|}{ Treated } \\
\hline Udeşti & Austrian & Udeşti - Ştirbăt & 50 \\
\hline Udeşti & Austrian & Ştirbăt - Udeşti & 50 \\
\hline Udeşti & Austrian & Udeşti - Poieni & 50 \\
\hline Udeşti & Austrian & Poieni - Udeşti & 50 \\
\hline Poieni & Austrian & Poieni - Udeşti - Ştirbăt & 50 \\
\hline Poieni & Austrian & Udeşti - Poieni - Ştirbăt & 50 \\
\hline \multicolumn{4}{|c|}{ Control } \\
\hline Ştirbăt & non-Austrian & Ştirbăt - Udeşti - Poieni & 50 \\
\hline Ştirbăt & non-Austrian & Udeşti - Ştirbăt - Poieni & 50 \\
\hline
\end{tabular}

\subsection{Experiment Implementation in the Udeşti Commune}

We employed the Bucharest-based research firm Cult Market Research (CMR) to implement the experiments on July 21-23, 2016. Six researchers from CMR carried out the experiments in secondary schools, spending one day in each village. Prior to conducting the experiments, CMR made local contacts to serve as field recruiters: 3 in Udeşti, 1 in Poieni, and 1 in Ştirbăt. These contacts were all well-known in their village and were introduced to CMR by the mayor. The field recruiters worked with two CMR researchers to organize the experiment (e.g., find a location) and sign up participants one week prior to implementation. The 
popularity of the field recruiters is one of the primary reasons we were able to achieve such high turnout for the experiment. And, luckily, the weather was beautiful the three days CMR conducted the experiment. ${ }^{18}$

Importantly, CMR was never informed about the natural experiment this paper exploits. We had many discussions with the CMR researchers regarding the implementation of the experiment, the villages involved, and the manner in which they would collect and input data, but we never discussed the old Austrian border central to our identification strategy. Hence, the experiment was double-blind, with neither participants nor experimenters knowing the research questions.

CMR conducted the experiment with 20-30 participants at a time, all playing the same treatment. Instructions were read aloud in Romanian, and all instructions and handouts were translated into Romanian. About $50 \%$ of participants needed additional explanations for at least one of the tasks, although all participants also took a quiz to test their understanding. Participants largely followed instructions and were silent during the experiment except when asking questions. Each session took about one hour to complete.

On the day of the experiment, participants received a 10 lei $(\$ 2.50)$ show-up fee, paid before the experiment began (to engender the belief that participants would indeed be paid). They were told that they could make much more during the experiment, and that in one week a representative of CMR would come back to the village to pay their earnings (beyond the show-up fee). After the experiment was conducted, the CMR researchers entered the data into a de-identified spreadsheet, which returned how much each participant earned in the experiment (participants were identified by a number, and CMR kept a separate spreadsheet that matched participants' names to their ID number). A CMR researcher returned one week later to pay participants their earnings. We unfortunately could not pay subjects their earnings immediately because payouts were contingent on decisions made in other villages.

\section{Testable Predictions}

Before proceeding to the experimental results, we propose numerous predictions regarding the actions of the participants. We do not propose a formal model in this section because the intuition for our predictions is taken from the literature and is straight-forward. We therefore do not need a model to generate unexpected or counter-intuitive predictions. We begin by listing predictions with respect to expected behavioral differences and proceed to provide predictions that would hold true if the mechanism is inter-generational cultural transmission.

First, we employ the literature on Austrian-Ottoman/Russian institutional differences overviewed in

${ }^{18}$ It is possible that field recruiters may have induced selectivity into the subject pool if, for example, one was less trusting of outsiders than the others. Even though we have no reason to believe this was the case, we cannot rule it out. However, we note that a non-trivial share of the entire village in each of the three villages participated in the experiment, limiting the effect that recruiter selection could have on the results. 
Section 2.1. This literature helps us generate predictions regarding the actions of participants on either side of the old border conditional on these differences being manifested to some degree today (possibly through inter-generational cultural transmission, which we turn to shortly). This literature suggests that the Austrian administration was relatively decentralized, efficient, well-respected, and free from corruption, while Ottoman and Russian administration was rapacious and predatory, extracting the maximum rents possible. It follows that people living in the Austrian lands should have had greater trust in government (Becker et al. 2016). Importantly, this type of trust was not generated by social ties or local norms. Instead, it was generated by those outside of one's social group, especially on the non-Austrian side of the border, where administrators' ties to the local community were often weak. This is a key distinction, because trust outside of one's social group is difficult to generate (Balliet, Wu, and De Dreu 2014), but it is one of the keys to facilitating impersonal exchange (Arrow 1972; Greif 1994, 2006). ${ }^{19}$ We therefore expect that, if norms generated by institutional differences in the 18th-19th century are "sticky" enough to still exist, people whose village was "treated" with Austrian institutions would trust outsiders more than people living on the non-Austrian side. ${ }^{20}$

Moreover, Section 2.2 suggests that there may have been selection into non-Austrian Ştirbăt and out of Austrian Udeşti in the late-18th century. Many migrants into Ştirbăt were native Moldavians escaping some form of repression in the recently-annexed Bukovina territory. With respect to trust attitudes, it follows that these migrants should have been more trusting of the people in the location they escaped to (Ştirbăt) and less trusting of people in places they escaped from (Udeşti). On the one hand, this fact muddles the proposed causal pathway, since the initial impetus causing differences in contemporary trust could be old AustrianOttoman-Russian institutional differences, late-18th century selection into non-Austrian Ştirbăt, or (likely) some combination of the two. There is no way of separating these competing causes, and we remain agnostic regarding which one is the driving force. However, the key question addressed in this paper is whether cultural differences generated long ago persist, whatever their origin. On this front, we are fortunate that selection into Ştirbăt yields the same prediction regarding trust of outsiders as do differences in Austrian and non-Austrian administration. Regardless of the initial cause of cross-border cultural differences, evidence of contemporary effects would indicate strong persistence.

\footnotetext{
${ }^{19}$ Becker et al. (2016) find no differences in either side of the old Austrian border on interpersonal trust in general. Their data do not allow them to speak to the outgroup-ingroup distinction we make in this paper.

${ }^{20}$ We cannot completely rule out the possibility that our experiment picks up trust (or mistrust) of people from the specific "outsider" village in question, rather than trust or mistrust of outsiders in general. Likewise, we cannot completely rule out the possibility that our results are reflective of different family structures across villages, which have been shown elsewhere to be tied to distrust of outsiders (Alesina and Giuliano 2014; Greif and Tabellini 2017; Enke 2017). Yet, the benefit of the natural experiment we exploit is that the salient difference across the villages was the political state in power. There is little reason to believe there are fundamentally different family structures across villages. Indeed, the founder of (non-Austrian) Ştirbăt (Madame Ruxanda Ştirbeţ) and her family had lived on the Austrian side of the border for at least a century before the partition (Marţolea 1986, p. 12).
} 
In the context of the trust game experiment, administrative differences and selection into non-Austrian Ştirbăt therefore yield the following prediction:

Prediction 1: Participants from the control village (non-Austrian Ştirbăt) will send less when playing the game with outsiders than will participants from the treated villages (Udeşti and Poieni). Within the treated villages, there will be no difference in the amount sent to outsiders.

The prediction with respect to how much one sends to co-villagers is not as straight-forward, as there are two countervailing factors at play. On the one hand, if people from the Austrian side are simply more trusting of others in general, including people from their own village, they should send more to co-villagers than people from the non-Austrian side. On the other hand, lower trust of outsiders on the non-Austrian side (Prediction 1) may have made intravillage trust all the more important, as the possibilities for exchange outside the village would have been lower (Greif 1994). If this effect is strong, it would entail that people on the non-Austrian side are more likely to trust co-villagers. Since it is unclear ex ante which effect is stronger and our experiment does not allow us to parse trust into these two countervailing effects, we do not make predictions with respect to trust of co-villagers. We can, however, make a statement about relative trust: i.e., how trusting people are of co-villagers relative to outsiders. The above discussion suggests that people from the non-Austrian side may be more trusting of co-villagers than people from the Austrian side, in which case (in combination with Prediction 1) the difference in trust between co-villagers and outsiders would be greater on the non-Austrian side. Yet, even if people from the non-Austrian side are less trusting of co-villagers because their general level of trust is lower, if this is at all counteracted by historic exchange opportunities, the difference in trust between co-villagers and outsiders should still be greater on the non-Austrian side, all else equal. In the context of the experiment, this insight yields the following prediction:

Prediction 2: The difference in the amount sent when playing the game with co-villagers versus outsiders will be greater for participants from the control village (non-Austrian Ştirbăt) than those from the treated villages (Udeşti and Poieni).

Next, we turn to the "return" decision made in the second stage of the trust game. The return decision does not measure trust. Instead, it measures trustworthiness; the receiver rewards a sender for trusting them, and they will have no further interaction nor will they ever know each other's identities. Trustworthiness is different from trust because it is conditional; it is only expressed when the other person exhibits trust in the first place. Nothing we know of in the Austrian-Ottoman-Russian literature sheds light on whether we should expect to see stronger trustworthiness from participants on one side of the border. Hence, we do not make a prediction with respect to the return decision. But these decisions are still important for 
our interpretation of the send decision. As Fershtman and Gneezy (2001) note, a sender could rationally mistrust the other group if participants from the other group are indeed likely to return less on average. This yields an interpretation that players are simply acting rationally, and that "statistical discrimination" may be an optimal strategy in the absence of other information. Hence, in the analysis we will note whether there is any evidence for rational statistical discrimination.

Finally, we turn to the cultural transmission mechanism. The most commonly accepted mechanism in the economics literature is the one proposed by Bisin and Verdier (2001), in which parents transmit their preferences to their children as a form of "parental altruism" (also see Nunn and Wantchekon 2011; Dohmen et al. 2012; Giuliano and Nunn 2017; Bisin and Verdier 2017; Iyigun and Rubin 2017; Roland and Yang 2017). This type of cultural transmission is denoted as vertical transmission (i.e., from parent to child). These preferences may also spread through the population either horizontally via peer group or obliquely via teaching (Bisin and Verdier 2008; Tabellini 2008; Guiso et al. 2008). Indeed, preferences may not even be transmitted directly from parent to child; transmission from one generation to the next can occur if children randomly sample the preferences of individuals from the older generation and take the average as their own preference (Boyd and Richerson 1985). While we cannot speak to the exact mechanism, given the simplicity of our experiment, our questionnaire does allow us to test an implication of the Bisin and Verdier model. ${ }^{21}$ If cultural transmission occurred in the villages, people whose families have lived in the village for multiple generations should be more likely to have the cultural traits predicted in Predictions 1 and $2 .^{22}$ To test this conjecture, the questionnaire administered after the experiment asked participants how long their families have lived in the village in question. While we arbitrarily set the cut-off in Prediction 3 at whether one's grandparents are from the village, we also test whether this prediction holds with respect to great-grandparents (results are reported in the Appendix).

Prediction 3: If cultural transmission occurred in the villages in the study, Predictions 1 and 2 should hold more strongly for participants whose grandparents (and previous generations) are from the village.

\footnotetext{
${ }^{21}$ We cannot speak directly to the idea that trust behavior is vertical transmitted via genetics. For instance, Cesarini et al. (2008) find that about half of variation in trust game behavior arises from genetic variation. Yet, the results we present in Section 5 indicate that it is not trust in general that differs by village but trust of outsiders. This finding is difficult to reconcile with a purely genetic view.

${ }^{22}$ Our questionnaire obtains family information via the question "To your knowledge, how long has your family lived in [village]?" (Question \#7, available in Appendix B.4). The possible answers are "You moved to [village] during your lifetime," "Your parents moved to [village]," "Your grandparents moved to [village]," "Your great-grandparents or an older generation moved to [village]," and "I don't know." We recognize that different subjects could take this question differently (i.e., some may answer "grandparents" if one grandparent is from the village while others may answer only if all four are). While this is a possibility, there is little reason why the propensity to answer in one way or another would differ across the three villages in question.
} 


\section{Results}

\subsection{Demographic Summary Statistics}

Before presenting the results of the experiment, we present balance tests across the treatment and control groups on basic demographic characteristics, derived from the survey administered after the experiment. The results are summarized in Table 2. Such balance is important; Alesina and la Ferrara (2002) suggest that poor educational or occupational outcomes (among other things) are associated with low trust. Hence, if our participant sample is skewed, it might be these demographic features driving any treatment differences we find, not "cultural" differences. Fortunately, our sample is mostly balanced. Around half of the participants were female in both the (Austrian) treatment and (non-Austrian) control groups. Likewise, there are no statistically significant differences between the average age or education level between participants within the treated and control groups. The average age in all three villages is in the mid-40s, around half of participants have a high school education. While an overwhelming majority of participants in all three villages are Eastern Orthodox, the proportion is higher in Ştirbăt than in the treated villages $(0.88$ vs. $0.96, \mathrm{p}=0.023) .{ }^{23}$ The other demographic characteristic that is statistically different between the treated and control groups is marital status. More participants in the treated group are married (0.65) than in the control village Ştirbăt $(0.53)$

Table 2: Summary Statistics, Demographics

\begin{tabular}{|c|c|c|c|c|c|}
\hline Side of Border & Female & Age & Married & $\begin{array}{l}\text { High School } \\
\text { or Above }\end{array}$ & $\begin{array}{c}\text { Eastern } \\
\text { Orthodox }\end{array}$ \\
\hline $\begin{array}{l}\text { Austrian } \\
\text { (Udeşti and Poieni) }\end{array}$ & $\begin{array}{c}0.53 \\
(0.03) \\
\mathrm{N}=300\end{array}$ & $\begin{array}{c}45.91 \\
(1.04) \\
\mathrm{N}=279\end{array}$ & $\begin{array}{c}0.65 \\
(0.03) \\
\mathrm{N}=298\end{array}$ & $\begin{array}{c}0.51 \\
(0.03) \\
\mathrm{N}=295\end{array}$ & $\begin{array}{c}0.88 \\
(0.02) \\
\mathrm{N}=296\end{array}$ \\
\hline $\begin{array}{l}\text { Non-Austrian } \\
\text { (Ştirbăt) }\end{array}$ & $\begin{array}{c}0.52 \\
(0.05) \\
\mathrm{N}=100\end{array}$ & $\begin{array}{c}43.01 \\
(2.03) \\
\mathrm{N}=94\end{array}$ & $\begin{array}{c}0.53 \\
(0.05) \\
\mathrm{N}=98\end{array}$ & $\begin{array}{c}0.45 \\
(0.05) \\
\mathrm{N}=94\end{array}$ & $\begin{array}{c}0.96 \\
(0.02) \\
\mathrm{N}=97\end{array}$ \\
\hline p-value: Diff in Means & 0.863 & 0.153 & $0.033^{*}$ & 0.273 & $0.023^{*}$ \\
\hline
\end{tabular}

Notes: Standard errors in parentheses. ${ }^{* *} p<0.01 ;{ }^{*} p<0.05$. p-values from Wilcoxon rank-sum (Mann-Whitney) test.

For the sake of a trust experiment, it is also desirable to have balance across occupations. It is possible that past institutional differences affect income or occupational mobility in the present, which itself could affect trust norms. To address this possibility, we report in Table 3 the participants' self-reported occupation.

${ }^{23}$ Importantly, the villages in the Udeşti commune have been overwhelmingly Eastern Orthodox since the time of the partition in 1774. Indeed, one of the first things Madame Ştirbet did (in 1781) upon moving to the new village of Ştirbăt was have a church built (Marţolea 1986, p. 12) 
This is our best indication of participants' economic status. While the unemployed (including housewives, house-husbands, retirees, and students) are over-represented, likely due to the nature of recruiting for a field experiment, there are no statistically significant differences in any of the set of occupations.

Table 3: Summary Statistics, Occupations

\begin{tabular}{lccccccc} 
Side of Border & Housewife & Student & Retired & Unemployed & Agric & Service & Blue Collar \\
\hline $\begin{array}{l}\text { Austrian } \\
\text { (Udeşti and Poieni) }\end{array}$ & 0.26 & 0.09 & 0.24 & 0.06 & 0.10 & 0.11 & 0.13 \\
$\mathrm{~N}=284$ & $(0.03)$ & $(0.02)$ & $(0.03)$ & $(0.01)$ & $(0.02)$ & $(0.02)$ & $(0.02)$ \\
& & & & & & & \\
$\begin{array}{l}\text { Non-Austrian } \\
\quad \text { Ştirbăt) }\end{array}$ & 0.28 & 0.13 & 0.24 & 0.07 & 0.04 & 0.10 & 0.12 \\
$\quad$ N =90 & $(0.05)$ & $(0.04)$ & $(0.05)$ & $(0.03)$ & $(0.02)$ & $(0.03)$ & $(0.03)$ \\
& & & & & & & \\
p-value: Diff in Means & 0.697 & 0.210 & 0.977 & 0.717 & 0.093 & 0.738 & 0.842 \\
\hline
\end{tabular}

Notes: Standard errors in parentheses. ${ }^{*} p<0.01{ }^{*} p<0.05$. p-values from Wilcoxon rank-sum (Mann-Whitney) test. "Housewife" includes housewives, househusbands, and those raising children. "Unemployed" includes self-identified unemployed and those who list job as "none". "Agriculture" includes agriculturalists, farmers, daysmen, and cattlemen. "Service" includes clothiers, sellers, drivers, personal assistants, bakers, caretakers, postal workers, teachers, city hall workers, freelancers, poets, partners, administrators, athletes, interior designers, postal workers, clerks, librarians, treasurers, and one economist. "Blue collar" includes those in construction, "workers," technicians, plumbers, car washers, mechanics, steel workers, security agents, and chambermaids. Four participants listed jobs we could not classify.

The theory laid out in Section 4 is based on cultural transmission. In particular, Prediction 3 indicates that outgroup trust should be different for those whose grandparents are from the village than for those whose grandparents are not. This argument is based on cultural transmission, not some other demographic detail that might differ between the two groups. Take, for instance, education or religion. It is possible that the centuries-old institutional differences noted in previous sections affect one's education or religion in the present, and it is education or religion in the present that affects trust, not "culture" (as in Alesina and la Ferrara 2002). In other words, what we are ascribing to culture may actually be mediated through some other educational or demographic feature. To address this possibility, we report in Table 4 the demographic summary statistics broken down by whether or not one's grandparents are from the village. The reported p-values are intra-village comparisons between those whose grandparents are and are not from the village. These results suggest that, within villages, participants whose grandparents are from the village are statistically similar to those whose grandparents are not from the village. This indicates that any results we find are unlikely to arise from mediation via some other channel. The one difference of potential concern is that participants from (non-Austrian) Ştirbăt whose grandparents are from Ştirbăt have higher education than those whose grandparents are not from Ştirbăt. This, however, should work against our hypotheses, which suggest that participants of Ştirbăt should be less trusting of outsiders. The standard result in the literature 
(Alesina and la Ferrara 2002) is that more education leads to greater trust, thus biasing against us finding lower trust in Ştirbăt.

Table 4: Demographic Summary Statistics, by History in Village

\begin{tabular}{|c|c|c|c|c|c|c|c|c|c|c|}
\hline \multirow[b]{2}{*}{$\begin{array}{l}\text { Grandparents } \\
\text { from Village? }\end{array}$} & \multicolumn{2}{|c|}{ Female } & \multicolumn{2}{|c|}{ Age } & \multicolumn{2}{|c|}{ Married } & \multicolumn{2}{|c|}{$\begin{array}{l}\text { High School } \\
\text { or Above }\end{array}$} & \multicolumn{2}{|c|}{$\begin{array}{l}\text { Eastern } \\
\text { Orthodox }\end{array}$} \\
\hline & Yes & No & Yes & No & Yes & No & Yes & No & Yes & No \\
\hline $\begin{array}{l}\text { Austrian } \\
\text { (Udesti and Poieni) }\end{array}$ & $\begin{array}{l}0.55 \\
(0.05)\end{array}$ & $\begin{array}{c}0.58 \\
(0.05)\end{array}$ & $\begin{array}{l}46.85 \\
(1.76)\end{array}$ & $\begin{array}{l}45.28 \\
(1.60)\end{array}$ & $\begin{array}{c}0.57 \\
(0.05)\end{array}$ & $\begin{array}{c}0.66 \\
(0.04)\end{array}$ & $\begin{array}{c}0.53 \\
(0.05)\end{array}$ & $\begin{array}{c}0.57 \\
(0.05)\end{array}$ & $\begin{array}{c}0.90 \\
(0.03)\end{array}$ & $\begin{array}{c}0.86 \\
(0.03)\end{array}$ \\
\hline $\mathrm{N}$ & 112 & 119 & 107 & 109 & 111 & 119 & 109 & 118 & 111 & 118 \\
\hline p-value: Diff in Means & \multicolumn{2}{|c|}{0.688} & \multicolumn{2}{|c|}{0.521} & \multicolumn{2}{|c|}{0.134} & \multicolumn{2}{|c|}{0.590} & \multicolumn{2}{|c|}{0.300} \\
\hline $\begin{array}{l}\text { Non-Austrian } \\
\text { (Ştirbăt) }\end{array}$ & $\begin{array}{l}0.56 \\
(0.10)\end{array}$ & $\begin{array}{c}0.58 \\
(0.08)\end{array}$ & $\begin{array}{l}36.72 \\
(3.79)\end{array}$ & $\begin{array}{l}43.65 \\
(3.07)\end{array}$ & $\begin{array}{c}0.44 \\
(0.10)\end{array}$ & $\begin{array}{c}0.51 \\
(0.08)\end{array}$ & $\begin{array}{c}0.63 \\
(0.09)\end{array}$ & $\begin{array}{c}0.35 \\
(0.07)\end{array}$ & $\begin{array}{l}1.00 \\
(0.00)\end{array}$ & $\begin{array}{r}0.93 \\
(0.04)\end{array}$ \\
\hline $\mathrm{N}$ & 27 & 43 & 25 & 43 & 27 & 43 & 27 & 43 & 27 & 43 \\
\hline p-value: Diff in Means & \multicolumn{2}{|l|}{0} & \multicolumn{2}{|c|}{0.169} & \multicolumn{2}{|c|}{0.} & \multicolumn{2}{|c|}{$0.023 *$} & \multicolumn{2}{|c|}{0.164} \\
\hline
\end{tabular}

Notes: Standard errors in parentheses. ${ }^{* *} p<0.01{ }^{*} p<0.05$. p-values are within village differences, taken from Wilcoxon rank-sum (Mann-Whitney) test.

Finally, we examine the degree to which participants trust others. The results are summarized in Table 5. We asked participants to rate how much they trust people in each of the three villages (from 1-5, with 1 being extremely untrustworthy and 5 being extremely trustworthy; see Appendix B.4 for details). ${ }^{24}$ Not surprisingly, participants tended to find people from their own village more trustworthy. Participants from both Austrian Udeşti and Poieni view people from non-Austrian Ştirbăt as less trustworthy than their covillagers while participants from Ştirbăt viewed their co-villagers as more trustworthy than people from Udeşti and Poieni. ${ }^{25}$ Yet, participants from the treated and control villages found their co-villagers about equally trustworthy (3.73 vs. 3.74 ) while also finding people from the opposite side of the old border equally (less) trustworthy. ${ }^{26}$ Within the treated group, it appears that participants from (Austrian) Udeşti and

\footnotetext{
${ }^{24}$ We asked more questions in the survey about trust in others and unofficial payments (i.e., bribes) one has to make to secure a variety of public goods. The results, reported in Appendix Table A1, suggest that $2 / 3$ of subjects felt they could trust others, and few regularly had to pay bribes. Although there are no statistically significant differences in trust between the treatment and control villages, the question does not ask about in-group vs. out-group, but about trust in general. We also asked questions about participants' financial history (i.e., borrowing and lending). The averages are reported in Appendix Table A2. The only statistically significant finding is that participants from Ştirbăt borrowed and lent more frequently to co-villagers than those from the treated villages.

${ }^{25}$ In the remainder of the paper, including Table 5, we use the term "outsider" simply to refer to those that live within the Udeşti commune but not within one's village. Our experiment does not permit us to test participants' trust of outsiders in general.

${ }^{26}$ In Appendix Table A3, we report the fraction of participants who answered each quiz question correctly as well as their average earnings from the experiment. These results are mixed. Participants from Ştirbăt correctly answered questions 1 and 2 more often than those from the Austrian villages, but the latter correctly answered questions 5 and 6 more frequently than the former. In general, participants from all three villages answered nearly $2 / 3$ of questions correctly on average. Although some participants did not do well on the quiz, we did not impose a threshold for playing. We do, however, control for their quiz score in the empirical analysis. Participants from Udeşti only played four rounds of the experiment, versus six rounds for participants from Poieni and Ştirbăt, and thus their earnings are not directly comparable. Participants in Poieni and Ştirbăt earned nearly the same amount (\$18.21 vs. $\$ 18.34)$.
} 
Poieni trust each other approximately the same, while trusting people from (non-Austrian) Ştirbăt less. ${ }^{27}$ This suggests the possibility that people on the opposite sides of the old border still consider each other "outsiders". However, it is important to note that these are the results of a non-incentivized survey, taken after participants played a variety of trust games. Hence, their responses may be affected by the game itself or their expectations of what the experimenters desired (given that they just played a trust game). We therefore focus on the incentivized trust games in the remainder of the analysis.

Table 5: Summary Statistics, Trust Others

\begin{tabular}{lcccc} 
Side of Border & $\begin{array}{c}\text { Trust } \\
\text { Co-villagers (1-5) }\end{array}$ & $\begin{array}{c}\text { Trust } \\
\text { Udeşti (1-5) }\end{array}$ & $\begin{array}{c}\text { Trust } \\
\text { Poieni (1-5) }\end{array}$ & $\begin{array}{c}\text { Trust } \\
\text { Ştirbăt (1-5) }\end{array}$ \\
\hline Austrian & 3.73 & 3.74 & 3.71 & 3.48 \\
(Udeşti and Poieni) & $(0.06)$ & $(0.05)$ & $(0.06)$ & $(0.06)$ \\
& $\mathrm{N}=280$ & $\mathrm{~N}=281$ & $\mathrm{~N}=284$ & $\mathrm{~N}=281$ \\
& & & & \\
Non-Austrian & 3.74 & 3.54 & 3.53 & 3.74 \\
(Ştirbăt) & $(0.11)$ & $(0.10)$ & $(0.11)$ & $(0.11)$ \\
& $\mathrm{N}=94$ & $\mathrm{~N}=93$ & $\mathrm{~N}=94$ & $\mathrm{~N}=94$ \\
& 0.595 & 0.068 & 0.121 & $0.002^{* *}$ \\
\hline
\end{tabular}

Notes: Standard errors in parentheses. ${ }^{* *} p<0.01{ }^{*} p<0.05$. p-values from Wilcoxon rank-sum (Mann-Whitney) test.

\subsection{Trust: The Send Decision}

Prediction 1 indicates that participants from the control village (non-Austrian) Ştirbăt will send less tokens than participants from the treated, Austrian villages (Udeşti and Poieni) when matched with outsiders. Meanwhile, Prediction 2 indicates that the difference in the amount sent to one's co-villagers versus outsiders should be greater in the control village (Ştirbăt) than in the treated, Austrian villages. Moreover, if intra-family, vertical cultural transmission is among the mechanisms connecting historically-derived cultural differences with contemporary trust norms, we expect these effects to be stronger for participants whose grandparents lived in their village (Prediction 3). ${ }^{28}$ Table 6 and Figure 5 report the results.

Figure 5 shows the average amount sent to one's co-villagers (column 1), sent to outsiders (column 2), and the fraction of participants who sent more to their co-villagers than to outsiders (column 3). The second and third rows break down these results by whether one's grandparents are from the village or not. ${ }^{29}$ While

${ }^{27}$ The average trust of people from Poieni by participants from Udeşti is 3.66 while the average trust of people from Udeşti by participants from Poieni is 3.76 .

${ }^{28}$ Appendix Table A5 provides the same information as Panel A of Table 6, but with the data broken down by whether one's great-grandparents are from the village or not. Results are similar to those reported in Table 6.

${ }^{29}$ The incentivized results reported in Table 6 show similar patterns to the self-reported levels of trust (see Table 5) when broken down by whether or not the participant's grandparent is from the village, although the inter-village differences are not statistically significant. These results are available upon request. 
breaking down results by family lineage does reduce the size of the samples, it comes with the benefit of permitting a test of Prediction 3, even if this test is somewhat underpowered. ${ }^{30}$

Figure 5: Average Amount Sent to Co-villagers and Outsiders
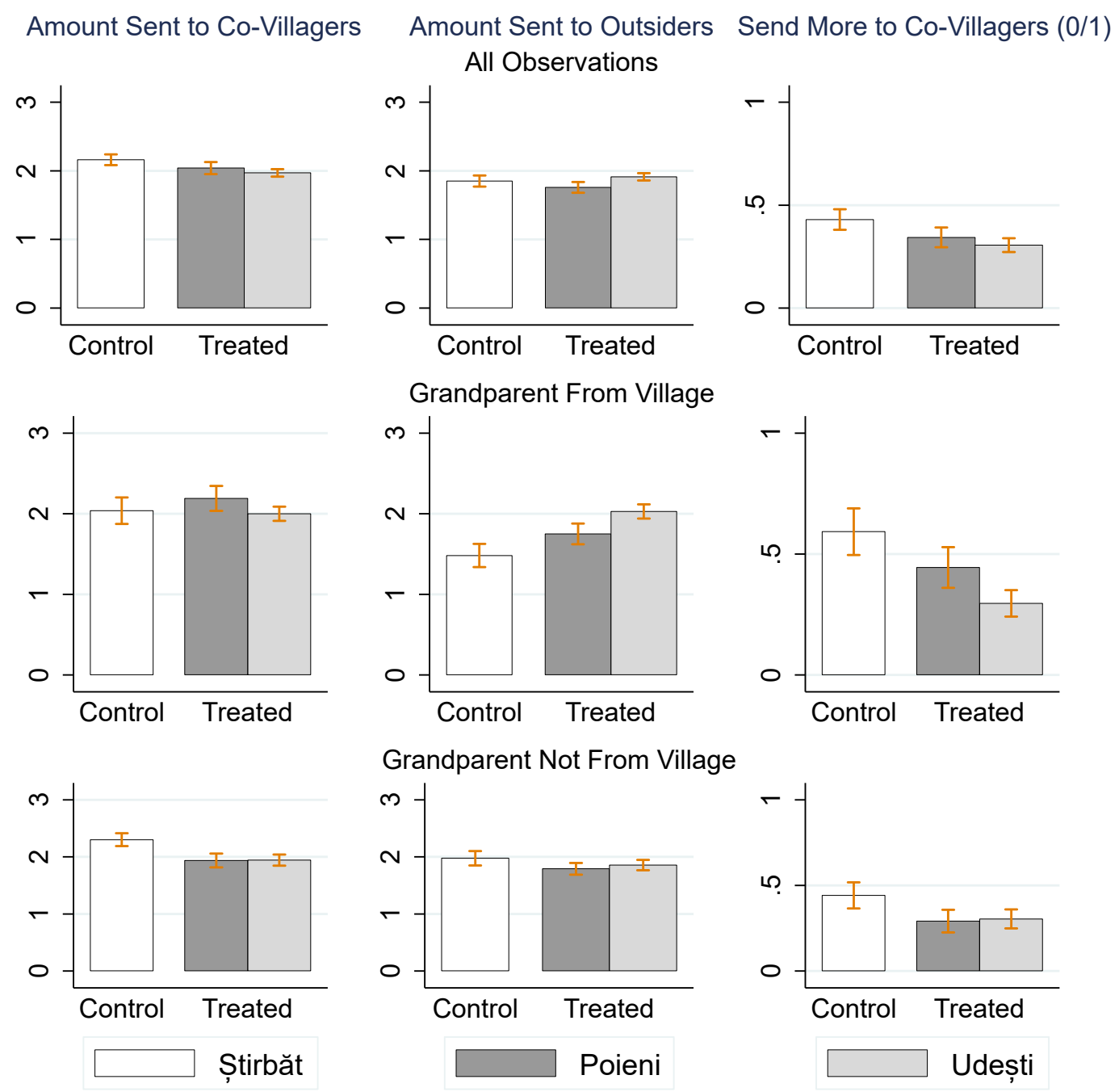

Consider first Prediction 1, which appears contradicted by the amount sent by all participants in the treated vs. control groups. The average amount sent to outsiders in the treated (Austrian) villages (1.86) is similar to the amount sent to outsiders in the control (non-Austrian) village $(1.85 ; \mathrm{p}=0.796)$. However, participants from Ştirbăt whose grandparents are from Ştirbăt send much less to outsiders than do participants from the treated villages whose grandparents are from the village (1.94 vs. $1.48 ; \mathrm{p}=0.007)$. Meanwhile,

\footnotetext{
${ }^{30}$ Unfortunately, the issue of the tests being underpowered is a reflection of just how small these villages are. In Ştirbăt and Poieni, around $1 / 3$ of all households in the village participated in our experiment, while in Udeşti, around $1 / 5$ of households participated. Thus, slicing the sample along any dimension creates a danger of an underpowered test. This lack of power is exacerbated when the treated villages are unpooled. Nonetheless, we report these results in Appendix Table A4. In terms of statistical significance, these results are broadly similar to those reported in Table 6 .
} 
Table 6: Average Amount Sent to Co-villagers and Outsiders

\begin{tabular}{|c|c|c|c|c|c|c|c|c|c|}
\hline & \multicolumn{3}{|c|}{ Sent to Co-villagers } & \multicolumn{3}{|c|}{ Sent to Outsiders } & \multicolumn{3}{|c|}{$\begin{array}{c}\text { Sent More to } \\
\text { Co-villagers }(0 / 1)\end{array}$} \\
\hline & \multicolumn{3}{|c|}{$\begin{array}{l}\text { Grandparents } \\
\text { from Village? }\end{array}$} & \multicolumn{3}{|c|}{$\begin{array}{l}\text { Grandparents } \\
\text { from Village? }\end{array}$} & \multicolumn{3}{|c|}{$\begin{array}{l}\text { Grandparents } \\
\text { from Village? }\end{array}$} \\
\hline & All & Yes & No & All & Yes & No & All & Yes & No \\
\hline & \multicolumn{9}{|c|}{ A. Treated (Austrian) vs. Control (Non-Austrian) } \\
\hline $\begin{array}{l}\text { Austrian } \\
\text { (Udeşti and Poieni) }\end{array}$ & $\begin{array}{c}1.99 \\
(0.05)\end{array}$ & $\begin{array}{c}2.06 \\
(0.08)\end{array}$ & $\begin{array}{c}1.94 \\
(0.08)\end{array}$ & $\begin{array}{c}1.86 \\
(0.04)\end{array}$ & $\begin{array}{c}1.94 \\
(0.07)\end{array}$ & $\begin{array}{l}1.83 \\
(0.07)\end{array}$ & $\begin{array}{c}0.32 \\
(0.03)\end{array}$ & $\begin{array}{c}0.35 \\
(0.05)\end{array}$ & $\begin{array}{c}0.30 \\
(0.04)\end{array}$ \\
\hline $\mathrm{N}$ & 298 & 111 & 118 & 294 & 108 & 118 & 292 & 107 & 117 \\
\hline $\begin{array}{l}\text { Non-Austrian } \\
\text { (Ştirbăt) }\end{array}$ & $\begin{array}{c}2.16 \\
(0.08)\end{array}$ & $\begin{array}{c}2.04 \\
(0.16)\end{array}$ & $\begin{array}{c}2.30 \\
(0.11)\end{array}$ & $\begin{array}{c}1.85 \\
(0.08)\end{array}$ & $\begin{array}{l}1.48 \\
(0.14)\end{array}$ & $\begin{array}{c}1.98 \\
(0.13)\end{array}$ & $\begin{array}{c}0.43 \\
(0.05)\end{array}$ & $\begin{array}{c}0.59 \\
(0.10)\end{array}$ & $\begin{array}{c}0.44 \\
(0.08)\end{array}$ \\
\hline $\mathrm{N}$ & 100 & 27 & 43 & 100 & 27 & 43 & 100 & 27 & 43 \\
\hline \multirow[t]{2}{*}{ p-value: Diff in Means } & 0.079 & 0.842 & $0.013^{*}$ & 0.796 & $0.007^{* *}$ & 0.317 & $0.044^{*}$ & $0.020^{*}$ & 0.092 \\
\hline & \multicolumn{9}{|c|}{ B. Small Villages } \\
\hline $\begin{array}{r}\text { Austrian } \\
\text { (Poieni) }\end{array}$ & $\begin{array}{c}2.04 \\
(0.09)\end{array}$ & $\begin{array}{c}2.19 \\
(0.15)\end{array}$ & $\begin{array}{c}1.94 \\
(0.12)\end{array}$ & $\begin{array}{c}1.67 \\
(0.09)\end{array}$ & $\begin{array}{c}1.72 \\
(0.15)\end{array}$ & $\begin{array}{l}1.71 \\
(0.12)\end{array}$ & $\begin{array}{c}0.43 \\
(0.05)\end{array}$ & $\begin{array}{c}0.44 \\
(0.08)\end{array}$ & $\begin{array}{c}0.40 \\
(0.07)\end{array}$ \\
\hline $\mathrm{N}$ & 100 & 37 & 48 & 99 & 36 & 48 & 99 & 36 & 48 \\
\hline $\begin{array}{l}\text { Non-Austrian } \\
\text { (Ştirbăt) }\end{array}$ & $\begin{array}{c}2.16 \\
(0.08)\end{array}$ & $\begin{array}{c}2.04 \\
(0.16)\end{array}$ & $\begin{array}{c}2.30 \\
(0.11)\end{array}$ & $\begin{array}{c}1.55 \\
(0.09)\end{array}$ & $\begin{array}{c}1.33 \\
(0.20)\end{array}$ & $\begin{array}{c}1.56 \\
(0.12)\end{array}$ & $\begin{array}{c}0.51 \\
(0.05)\end{array}$ & $\begin{array}{c}0.52 \\
(0.10)\end{array}$ & $\begin{array}{c}0.56 \\
(0.08)\end{array}$ \\
\hline $\mathrm{N}^{3}$ & 100 & 27 & 43 & 100 & 27 & 43 & 100 & 27 & 43 \\
\hline \multirow[t]{2}{*}{ p-value: Diff in Means } & 0.392 & 0.400 & $0.036^{*}$ & 0.322 & 0.100 & 0.335 & 0.286 & 0.563 & 0.124 \\
\hline & \multicolumn{9}{|c|}{ C. Treated Villages } \\
\hline $\begin{array}{r}\text { Austrian } \\
\text { (Udeşti) }\end{array}$ & $\begin{array}{c}1.97 \\
(0.05)\end{array}$ & $\begin{array}{c}2.00 \\
(0.09)\end{array}$ & $\begin{array}{c}1.94 \\
(0.10)\end{array}$ & $\begin{array}{c}1.91 \\
(0.05)\end{array}$ & $\begin{array}{c}2.03 \\
(0.09)\end{array}$ & $\begin{array}{l}1.86 \\
(0.09)\end{array}$ & $\begin{array}{c}0.31 \\
(0.03)\end{array}$ & $\begin{array}{c}0.30 \\
(0.05)\end{array}$ & $\begin{array}{c}0.30 \\
(0.06)\end{array}$ \\
\hline $\mathrm{N}$ & 198 & 74 & 70 & 195 & 72 & 70 & 193 & 71 & 69 \\
\hline $\begin{array}{r}\text { Austrian } \\
\text { (Poieni) }\end{array}$ & $\begin{array}{c}2.04 \\
(0.09)\end{array}$ & $\begin{array}{l}2.19 \\
(0.15)\end{array}$ & $\begin{array}{c}1.94 \\
(0.12)\end{array}$ & $\begin{array}{l}1.76 \\
(0.08)\end{array}$ & $\begin{array}{l}1.75 \\
(0.13)\end{array}$ & $\begin{array}{l}1.79 \\
(0.10)\end{array}$ & $\begin{array}{c}0.34 \\
(0.05)\end{array}$ & $\begin{array}{c}0.44 \\
(0.08)\end{array}$ & $\begin{array}{c}0.29 \\
(0.07)\end{array}$ \\
\hline $\mathrm{N}$ & 100 & 37 & 48 & 99 & 36 & 48 & 99 & 36 & 48 \\
\hline p-value: Diff in Means & 0.380 & 0.145 & 0.947 & 0.199 & 0.089 & 0.785 & 0.513 & 0.128 & 0.883 \\
\hline
\end{tabular}

Notes: Standard errors in parentheses. ${ }^{* *} p<0.01{ }^{*} p<0.05$. p-values from Wilcoxon rank-sum (Mann-Whitney) test. Sent More to Co-villagers $=1$ if participant sent more to co-villagers than to outsiders. In the panels $\mathrm{A}$ and $\mathrm{C}$, outsiders are defined as the other village one played with in the first four rounds. In panel B, outsiders are defined as the other village one played with in the final two rounds. 
there is no statistically significant difference in the amount sent to outsiders across villages among participants whose grandparents are not from the village $(1.83$ vs. $1.98 ; \mathrm{p}=0.317)$. In fact, within this group the average amount sent is larger for participants from (non-Austrian) Ştirbăt.

One confounding factor in our analysis is that one of the villages in the treated group, Udeşti, is larger than the other two villages (1,100 househoulds vs. around 300 households in the other two villages). We address this issue in panel B of Table 6, which compares only the two smallest villages, Poieni and Ştirbăt. While this comparison lacks power, the results with respect to the amount sent to outsiders is similar to those reported in panel A. Comparing the final two rounds of play (in which participants from Ştirbăt played with those from Poieni and vice versa), we find that participants from the two villages send a similar amount to outsiders (1.67 vs. $1.55 ; \mathrm{p}=0.322)$. However, among those with a grandparent from the village, those from the control village (Ştirbăt) send much less than those from the treated village (1.72 vs. 1.33; p = $0.100)$.

Finally, in panel $\mathrm{C}$ of Table 6, we compare the two treated villages. According to Prediction 1, we should not see differences in sending behavior across these villages. Indeed, with respect to the amount sent to outsiders, this is broadly what we find (1.91 vs. $1.76 ; \mathrm{p}=0.199)$. While there does appear to be a difference among those whose grandparents are from the village (2.03 vs. $1.75 ; \mathrm{p}=0.089)$, these amounts remain much larger than in the control village (1.48).

Hence, after accounting for family ties within the village, the experiment results lend support to Predictions 1 and 3. We summarize these results as follows:

Result 1: Participants from the control village (Ştirbăt) whose grandparents are from Ştirbăt send less when playing with outsiders than do participants from the treated (Austrian) villages whose grandparents are from the village.

Prediction 2 states that the amount sent to one's co-villagers relative to the amount sent to outsiders should be greater in the control village (non-Austrian Ştirbăt) than in the treated, Austrian villages. To test this prediction, the third column of Figure 5 reports the fraction of participants who sent more to co-villagers than to outsiders. ${ }^{31}$ As suggested by Prediction 2, a greater fraction of participants from the control (non-Austrian) village send more to their co-villagers than participants from the treated (Austrian) villages (0.32 vs. $0.43 ; \mathrm{p}=0.044)$. This is true whether or not one's grandparents are from the village, although for different reasons. Among participants whose grandparents are not from the village, those from (non-Austrian) Ştirbăt send much more to their co-villagers than do those from the treated villages (1.94

${ }^{31}$ We also analyzed the difference in the total amount sent to co-villagers and outsiders. All results are similar in terms of statistical significance to the results pertaining to the fraction of participants who sent more to co-villagers than to outsiders. For the sake of brevity we do not include these statistics. 
vs. $2.30 ; \mathrm{p}=0.013)$. We will return to this observation shortly. Meanwhile, among participants whose grandparents are from the village, Result 1 noted that those from Ştirbăt send much less to outsiders than do those from the two treated villages. These results are summarized as follows:

Result 2: Participants from the control village (Ştirbăt) are more likely to send more to their co-villagers than to outsiders than participants from the treated (Austrian) villages.

Finally, we address a possible explanation for the finding that, among participants whose grandparents are not from the village, those from the control village (non-Austrian Ştirbăt) send more to their co-villagers than do those from the treated, Austrian villages. One possible explanation is that newcomers selectively chose the village in which they currently reside. That is, if they chose to live in their current village because they found people in that village to be particularly trustworthy, they may send more to co-villagers than those whose families have lived there multiple generations. And, if people from Ştirbăt are indeed particularly trustworthy, at least with respect to their co-villagers, this selection effect could contribute to our finding.

To address this possibility, we run ordered probit regressions on the amount participants sent to covillagers and outsiders, controlling for numerous individual characteristics. ${ }^{32}$ We also control for order effects, ${ }^{33}$ the participant's quiz score, and demographic controls including a gender dummy, age, age squared, marital status, a high school education dummy, an Eastern Orthodox dummy, religiosity, and occupational status. The results are reported in Table $7 .{ }^{34}$

The results are broadly consistent with what we find in the comparison of means. There does not appear to be a "Ştirbăt effect" in the amount sent to outsiders (columns (3)-(4)), although subjects whose grandparents are from Ştirbăt send significantly less to outsiders (consistent with Result 1). There does appear to be a "Ştirbăt effect" with respect to the amount sent to co-villagers: the Ştirbăt dummy coefficient is positive and statistically significant in specification (2). The coefficient on the "Grandparents from Village * Ştirbăt" interaction term indicates that this effect may be driven by subjects whose grandparents are not from the village, although this coefficient is not statistically significant. In other words, while we find a "Ştirbăt effect" - participants from Ştirbăt send more to their co-villagers than do those from the treated villages - we cannot say with statistical precision that this effect is confined to those who do or do not have a grandparent from the village.

These results raise the question: why is there a "Ştirbăt effect" in the amount sent to one's co-villagers that transcends one's family's ties to the village? Such an effect would be consistent with people from Ştirbăt

\footnotetext{
${ }^{32}$ Linear probability model estimates are similar in terms of statistical significance. These results are available upon request.

${ }^{33}$ The order of game play is statistically significant in many of the specifications, consistent with decay found in repeated economic experiments.

${ }^{34}$ In Appendix Table A6 we include potentially endogenous regressors, i.e., those related to trust. Results are broadly similar to the ones reported in Table 7. There is a reduced sample size in Table 7 because not all participants knew whether their grandparents came from the village, and a few participants failed to answer the survey question.
} 
Table 7: Ordered Probit Regressions: Average Amount Sent to Co-villagers and Outsiders

(1) (2) (3) (4)

\begin{tabular}{lcccc} 
Dependent Variable: & Sent to & $\begin{array}{c}(2) \\
\text { Co-villagers }\end{array}$ & $\begin{array}{c}(3) \\
\text { Sent to }\end{array}$ & $\begin{array}{c}(4) \\
\text { Outsiders }\end{array}$ \\
\hline Ştirbăt Dummy & & & & \\
& 0.26 & $0.44^{*}$ & 0.10 & 0.33 \\
Grandparents from & $(0.15)$ & $(0.22)$ & $(0.15)$ & $(0.21)$ \\
Village Dummy & & 0.11 & & 0.12 \\
Grandparents from & & $(0.16)$ & & $(0.16)$ \\
Village * Shtirbăt & & -0.45 & & $-0.91^{* *}$ \\
Order: Own First & -0.26 & -0.13 & $-0.51^{* *}$ & $-0.348^{*}$ \\
& $(0.13)$ & $(0.15)$ & $(0.13)$ & $(0.15)$ \\
Know Someone & 0.15 & 0.11 & 0.02 & 0.03 \\
From Other Village & $(0.16)$ & $(0.17)$ & $(0.15)$ & $(0.17)$ \\
& & & & \\
N & 336 & 264 & 332 & 260 \\
Pseudo R-squared & 0.03 & 0.03 & 0.04 & 0.05 \\
\hline \multirow{2}{*}{ QUIZ SCORE } & & & & \\
DEMOGRAPHIC & YES & YES & YES & YES \\
& & & & YES \\
\hline
\end{tabular}

Notes: Ordered probit coefficients reported. Standard errors in parentheses. ${ }^{* *} p<0.01 ;{ }^{*} p<0.05$. Quiz Score is number correct out of 6 on incentivized quiz. Demographic characteristics are a gender dummy, age, age squared, married dummy, high school education dummy, Eastern Orthodox dummy, dummy for whether subjects attend religious services, and dummies for occupation type (not employed, blue collar, agriculture, service, and other). Outsiders are defined as the outside village one played with in the first four rounds.

being more trustworthy; i.e., more likely to return tokens to their co-villagers. We address this question in the following section by analyzing the participants' return decisions.

\subsection{Trustworthiness: The Return Decision}

In Section 4, we made no predictions regarding the return decision. Yet, these results may shed light on the "Ştirbăt effect" from Result 2, namely that participants from (non-Austrian) Ştirbăt send more to their co-villagers than do those from the treated, Austrian villages regardless of their family history in the village. If people from Ştirbăt are indeed more trustworthy (i.e., they return more conditional on the amount sent), their fellow villagers could know this and accordingly send more to their co-villagers, regardless of how long their family lived in the village. Such a choice would be rational "statistical discrimination," as discussed in Fershtman and Gneezy (2001).

To this end, we analyze the amount returned to co-villagers and outsiders conditional on the sender they were matched with sending 1,2 , or 3 tokens. The results are summarized in Table 8 and Figure $6 .^{35}$ These results indicate that rational, statistical discrimination can explain at least part of the "Ştirbăt

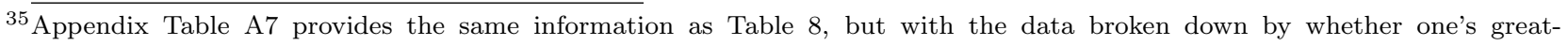


effect". Participants from Ştirbăt returned more to co-villagers than those from the treated, Austrian villages conditional on being sent 2 tokens (3.36 vs. $3.65 ; \mathrm{p}=0.052)$ and conditional on being sent 3 tokens $(4.82$ vs. 5.26; $\mathrm{p}=0.128)$. Although statistically imprecise, this indicates that it is rational for participants from Ştirbăt to send more to their co-villagers.

Table 8: Average Amount Returned to Co-villagers and Outsiders

\begin{tabular}{|c|c|c|c|c|c|c|c|c|c|}
\hline & \multicolumn{3}{|c|}{ If Sent 1} & \multicolumn{3}{|c|}{ If Sent 2} & \multicolumn{3}{|c|}{ If Sent 3} \\
\hline & & \multicolumn{2}{|c|}{$\begin{array}{l}\text { Grandparents } \\
\text { from Village? }\end{array}$} & & \multicolumn{2}{|c|}{$\begin{array}{l}\text { Grandparents } \\
\text { from Village? }\end{array}$} & \multicolumn{3}{|c|}{$\begin{array}{l}\text { Grandparents } \\
\text { from Village? }\end{array}$} \\
\hline & All & Yes & No & All & Yes & No & All & Yes & No \\
\hline & \multicolumn{9}{|c|}{ Returned to Co-villagers } \\
\hline $\begin{array}{l}\text { Austrian } \\
\text { (Udeşti and Poieni) }\end{array}$ & $\begin{array}{c}2.00 \\
(0.04)\end{array}$ & $\begin{array}{c}1.87 \\
(0.08)\end{array}$ & $\begin{array}{c}2.08 \\
(0.07)\end{array}$ & $\begin{array}{c}3.36 \\
(0.08)\end{array}$ & $\begin{array}{c}3.30 \\
(0.13)\end{array}$ & $\begin{array}{c}3.43 \\
(0.13)\end{array}$ & $\begin{array}{c}4.82 \\
(0.13)\end{array}$ & $\begin{array}{c}4.90 \\
(0.21)\end{array}$ & $\begin{array}{c}4.91 \\
(0.21)\end{array}$ \\
\hline $\mathrm{N}$ & 297 & 110 & 119 & 295 & 109 & 119 & 292 & 108 & 118 \\
\hline $\begin{array}{l}\text { Non-Austrian } \\
\text { (Ştirbăt) }\end{array}$ & $\begin{array}{c}2.00 \\
(0.08)\end{array}$ & $\begin{array}{c}1.96 \\
(0.16)\end{array}$ & $\begin{array}{c}2.05 \\
(0.10)\end{array}$ & $\begin{array}{c}3.65 \\
(0.16)\end{array}$ & $\begin{array}{c}3.48 \\
(0.36)\end{array}$ & $\begin{array}{c}3.60 \\
(0.25)\end{array}$ & $\begin{array}{c}5.26 \\
(0.24)\end{array}$ & $\begin{array}{c}4.85 \\
(0.49)\end{array}$ & $\begin{array}{c}5.28 \\
(0.32)\end{array}$ \\
\hline $\mathrm{N}$ & 99 & 27 & 43 & 98 & 27 & 42 & 99 & 27 & 43 \\
\hline \multirow[t]{2}{*}{ p-value: Diff in Means } & 0.964 & 0.661 & 0.710 & 0.052 & 0.627 & 0.436 & 0.128 & 0.813 & 0.342 \\
\hline & \multicolumn{9}{|c|}{ Returned to Outsiders } \\
\hline $\begin{array}{l}\text { Austrian } \\
\text { (Udeşti and Poieni) }\end{array}$ & $\begin{array}{l}1.78 \\
(0.04)\end{array}$ & $\begin{array}{c}1.80 \\
(0.07)\end{array}$ & $\begin{array}{c}1.76 \\
(0.07)\end{array}$ & $\begin{array}{c}3.24 \\
(0.08)\end{array}$ & $\begin{array}{c}3.17 \\
(0.14)\end{array}$ & $\begin{array}{c}3.30 \\
(0.14)\end{array}$ & $\begin{array}{c}4.71 \\
(0.13)\end{array}$ & $\begin{array}{c}4.67 \\
(0.20)\end{array}$ & $\begin{array}{c}4.81 \\
(0.21)\end{array}$ \\
\hline $\mathrm{N}$ & 298 & 111 & 118 & 297 & 110 & 118 & 294 & 108 & 118 \\
\hline $\begin{array}{l}\text { Non-Austrian } \\
\text { (Ştirbăt) }\end{array}$ & $\begin{array}{c}1.92 \\
(0.09)\end{array}$ & $\begin{array}{c}1.69 \\
(0.15)\end{array}$ & $\begin{array}{c}1.90 \\
(0.13)\end{array}$ & $\begin{array}{c}3.52 \\
(0.16)\end{array}$ & $\begin{array}{c}2.92 \\
(0.30)\end{array}$ & $\begin{array}{c}3.62 \\
(0.25)\end{array}$ & $\begin{array}{c}5.26 \\
(0.26)\end{array}$ & $\begin{array}{c}4.19 \\
(0.50)\end{array}$ & $\begin{array}{c}5.22 \\
(0.37)\end{array}$ \\
\hline $\mathrm{N}$ & 96 & 26 & 41 & 97 & 26 & 42 & 97 & 27 & 41 \\
\hline p-value: Diff in Means & 0.117 & 0.445 & 0.295 & 0.130 & 0.345 & 0.261 & $0.047^{*}$ & 0.345 & 0.357 \\
\hline
\end{tabular}

Notes: Standard errors in parentheses. ${ }^{* *} p<0.01{ }^{*} p<0.05$. p-values from Wilcoxon rank-sum (Mann-Whitney) test.

Likewise, trustworthiness may provide an explanation for why people whose grandparents are from nonAustrian Ştirbăt send less to outsiders than people whose grandparents are from the treated, Austrian villages (Result 1). The average amounts returned to outsiders conditional on the amount sent are summarized in the bottom panel of Table 8. The results indicate that participants from Ştirbăt do indeed return more to outsiders than those from the treated villages conditional on being sent 2 tokens (3.24 vs. $3.52 ; \mathrm{p}=0.130$ ) and conditional on being sent 3 tokens ( 4.71 vs. $5.26 ; \mathrm{p}=0.047$ ). However, these results are not driven by participants whose grandparents are from the village. There is no statistically significant difference in the amount returned between the two villages among participants whose grandparents are from the village; if anything, those from Ştirbăt return less. Moreover, within Ştirbăt, participants whose grandparents are from the village return less than those whose grandparents are not from the village conditional on being sent grandparents are from the village or not. Results are similar to those reported in Table 8 
Figure 6: Average Amount Returned to Co-villagers and Outsiders
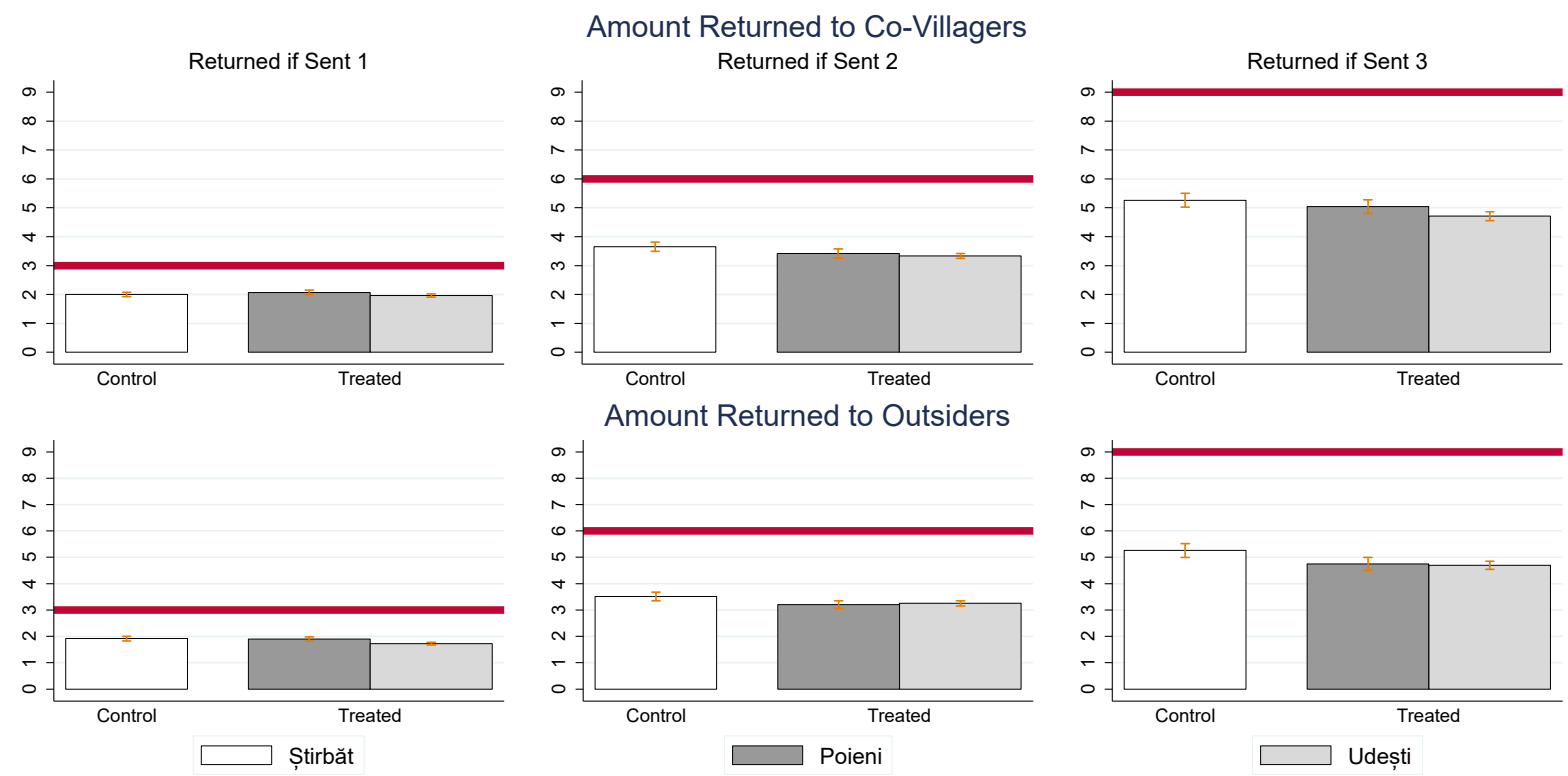

2 tokens $(2.92$ vs. $3.62 ; \mathrm{p}=0.052)$ or 3 tokens $(4.19$ vs. $5.22 ; \mathrm{p}=0.111)$. Meanwhile, within the treated villages, participants whose grandparents are from the village return a statistically indistinguishable amount from those whose grandparents are not from the village conditional on being sent 2 tokens (3.17 vs. $3.30 ; \mathrm{p}$ $=0.320)$ or 3 tokens (4.67 vs. $4.81 ; \mathrm{p}=0.622$ ).

These results make it difficult to reconcile Result 1 with a purely "statistical discrimination" viewpoint. Such an explanation would require participants whose grandparents are from the treated, Austrian villages believing that outsiders will return more than those whose grandparents are from the control village. Even though this is correct, this result is driven by participants whose grandparents are not from the village in question. Hence, while it is possible that the presence of statistical discrimination is a reflection of cultural differences generated by the old Austrian border, the most likely explanation for Result 1 remains that outgroup trust-rational or not-is weaker on the non-Austrian side of the border. These findings are summarized as follows:

Result 4: Participants in the treated (Austrian) villages return less to both co-villagers and outsiders than do those from the control (non-Austrian) village. There are no statistically significant differences in the amount returned between the treated and control villages when the sample is split between those whose grandparents are and are not from the village. 


\section{Conclusion}

This paper takes advantage of a natural experiment to shed light on whether norms derived from historical circumstances persist in the long run. We run a "lab in the field" trust game experiment in three villages in northeastern Romania, which were on opposite sides of the old Austrian border for over a century for arbitrary, idiosyncratic reasons. The arbitrariness of the border placement in combination with the wellknown differences in Austrian and Ottoman/Russian institutions and centuries-old migration patterns makes this an ideal environment to test whether cultural norms that arose due to historical reasons persist in the long run. Ottoman and Russian administrative institutions were famously rapacious and harmful to commerce, and the literature suggests this eroded trust in government in the former Ottoman/Russian lands. Meanwhile, villages "treated" with the relatively efficient and corruption-free Austrian administration were potentially motivated to trust outsiders - all three empires were outsiders to Romanians. We hypothesize that these historical differences should have fostered the emergence of different trust norms in the two regions, with people on the "treated" Austrian side of the border being more trusting of outsiders. We further hypothesize that, if trust norms are indeed passed on inter-generationally (i.e., vertically), these inter-village differences should be most apparent among participants whose grandparents are from the village. Their grandparents would have lived, or lived with people who lived, while the border differences existed, and thus possibly would have been imbued with these cultural attributes at an early age.

Our results confirm most of these hypotheses. Most strikingly, when participants played the game with outsiders, there was no difference between the treated and control villages in the amount sent. However, focusing on the overall average masks significant heterogeneity within the village: while there were no differences in the amount sent by people whose grandparents were not from their home village, people whose grandparents grew up in the village on the treated (Austrian) side sent significantly more to outsiders than people whose grandparents grew up in the control (non-Austrian) side.

While these results permit alternative hypotheses - perhaps people whose grandparents are from this one village in northeastern Romania are just less trusting of outsiders for some idiosyncratic reason besides cultural transmission - our methodology and the complementary literature suggest that these results are indeed reflective of the cultural transmission of norms established over a century ago. First, we chose to run the experiments in three small villages in which we had ex ante hypotheses for how participants in the

village would act. These hypotheses are largely confirmed by the experiments. Second, the experiment was run double-blind, so the experimenters could not subconsciously affect the outcomes in favor of the proposed hypotheses. Third, the results supported the sub-hypotheses that the differences would largely arise from participants whose grandparents were from the villages (admittedly, we were surprised by how strong these 
findings were). Fourth, these findings are consistent with a larger literature suggesting that Austrian and Ottoman/Russian institutions had long run, still present effects on trust.

These results have implications for the role that culture can play in affecting economic outcomes and vice versa. By identifying a cultural attribute that arguably has economic and institutional antecedents, we avoid conflating the direction of causality. We also show that once a trait becomes imbued in a society's (or, in our case, village's) culture, it can remain in spite of economic and political changes which entail that the cultural trait is not necessarily a best response. Although we do not wish to push results from an experiment in one Romanian commune too far, this insight has broad implications for the role that culture plays in the evolution - or lack thereof - of economic and political institutions (also see Bisin and Verdier 2017, Iyigun and Rubin 2017). If culture is indeed as "sticky" as our results suggest, it is difficult, if not impossible, to understand the role of institutions on decision-making unless one also understands how a society's culture (and, possibly, its historical antecedents) interacts with institutions to incentivize behavior.

\section{References}

Acemoglu, Daron, Simon Johnson, and James A. Robinson. 2001. "The Colonial Origins of Comparative Development: An Empirical Investigation." American Economic Review 91(5): 1369-401.

Adida, Claire, David D. Laitin, and Marie-Anne Valfort. 2016. Why Muslim Integration Fails in ChristianHeritage Societies. Cambridge, MA: Harvard University Press.

Aghion, Philippe, Yann Algan, Pierre Cahuc, Andrei Shleifer. 2010. "Regulation and Distrust." Quarterly Journal of Economics 125(3): 1015-49

Alesina, Alberto and Paola Giuliano. 2014. "Family Ties." Handbook of Economic Growth 2: 177-215.

Alesina, Alberto and Paola Giuliano. 2015. "Culture and Institutions." Journal of Economic Literature 53(4): $898-944$.

Alesina, Alberto, Paola Giuliano, and Nathan Nunn. 2013. "On the Origins of Gender Roles: Women and the Plough." Quarterly Journal of Economics 128(2): 469-530.

Alesina, Alberto and Eliana La Ferrara. 2002. "Who Trusts Others?" Journal of Public Economics 85(2): 207-34.

Algan, Yann and Pierre Cahuc. 2010. "Inherited Trust and Growth." American Economic Review 100(5): 2060-92.

Algan, Yann and Pierre Cahuc. 2013. "Trust and Human Development: Overview and Policy Implications." In Handbook of Economic Growth, Philippe Aghion and Steven N. Durlauf (Eds.). Vol. 1A.

Alston, Lee J., Marcus André Melo, Bernardo Mueller, and Carlos Pereira. 2016. Brazil in Transition: Beliefs, Leadership, and Institutional Change. Princeton: Princeton University Press.

Arrow, Kenneth J. 1972. "Gifts and Exchanges." Philosophy and Public Affairs 1(4): 343-62.

Bahry, Donna, Mikhail Kosolapov, Polina Kozyreva, and Rick K. Wilson. 2005. "Ethnicity and Trust: Evidence from Russia." American Political Science Review 99(4): 521-32.

Balla, Eliana and Noel D. Johnson. 2009. "Fiscal Crisis and Institutional Change in the Ottoman Empire and France." Journal of Economic History 69(3): 809-45. 
Balliet, Daniel, Junhui Wu, and Carsten K.W. De Dreu. 2014. "Ingroup Favoritism in Cooperation: A Meta-Analysis." Psychological Bulletin 140(6): 1556-81.

Barkey, Karen. 1994. Bandits and Bureaucrats: The Ottoman Route to State Centralization. Ithaca: Cornell University Press.

Barr, Abigail M. 2003. "Trust and Expected Trustworthiness: Experimental Evidence from Zimbabwean Villages." Economic Journal 113(489): 614-30.

Becker, Sascha O., Katrin Boeckh, Christa Hainz, and Ludger Woessmann. 2016. "The Empire is Dead, Long Live the Empire! Long-Run Persistence of Trust and Corruption in the Bureaucracy." Economic Journal 126(590): 40-74.

Berg, Joyce, John Dickhaut, and Kevin McCabe. 1995. "Trust, Reciprocity, and Social History." Games and Economic Behavior 10(1): 122-42.

Bigoni, Maria, Stefania Bortolotti, Marco Casari, Diego Gambetta and Francesca Pancotto. 2016. "Amoral Familism, Social Capital, or Trust? The Behavioural Foundations of the Italian North-South Divide." Economic Journal 126(594): 1318-41.

Bisin, Alberto, and Thierry Verdier. 2001. "The Economics of Cultural Transmission and the Dynamics of Preferences." Journal of Economic Theory 97: 298-319.

Bisin, Alberto, and Thierry Verdier. 2008. "Cultural Transmission." In: The New Palgrave Dictionary of Economics, 2nd Edition, Steven N. Durlauf and Lawrence E. Blume (Eds.). New York: Palgrave McMillan.

Bisin, Alberto, and Thierry Verdier. 2017. "On the Joint Evolution of Culture and Institutions." NBER Working Paper No. 23375.

Boyd, Robert, and Peter J. Richerson. 1985. Culture and the Evolutionary Process. Chicago: University of Chicago Press.

Brewer, Marilynn B. 1999. "The Psychology of Prejudice: Ingroup Love and Outgroup Hate?." Journal of Social Issues 55(3): 429-44.

Brown, Rupert. 2000. "Social Identity Theory: Past Achievements, Current Problems and Future Challenges." European Journal of Social Psychology 30(6): 745-78.

Buggle, Johannes. 2016. "Law and Social Capital: Evidence from the Cod Napoleon in Germany." European Economic Review 87: 148-175.

Butler, Jeffrey V., Paola Giuliano, and Luigi Guiso. 2016. "The Right Amount of Trust." Journal of the European Economic Association 14(5): 1155-80.

Cassar, Alessandra, Giovanna d'Adda, and Pauline Grosjean. 2013. "Institutional Quality, Culture, and Norms of Cooperation: Experimental Evidence from Italy and Kosovo." Journal of Law and Economics 57(3): 821-63.

Cesarini, David, Christopher T. Dawes, James H. Fowler, Magnus Johannesson, Paul Lichtenstein and Björn Wallace. 2008. "Heritability of Cooperative Behavior in the Trust Game." PNAS 105(10): 3721-26.

Chaudhary, Latika, Jared Rubin, Sriya Iyer, and Anand Shrivastava. 2017. "Cultural Transmission and the Colonial Legacy." Working Paper.

Chen, Yan, and Sherry Xin Li. 2009. "Group Identity and Social Preferences." American Economic Review 99(1): 431-57.

Coşgel, Metin M., Boğac Ergene, Haggay Etkes, and Thomas J. Miceli. 2013. "Crime and Punishment in Ottoman Times: Corruption and Fines." Journal of Interdisciplinary History 43(3): 353-76. 
David, Paul A. 1994. "Why Are Institutions the 'Carriers of History'? Path Dependence and the Evolution of Conventions, Organizations, and Institutions." Structural Change and Economic Dynamics 5: 205-20.

Dell, Melissa. 2010. "The Persistent Effects of Peru's Mining Mita." Econometrica 78(6): 1863-903.

Dell, Melissa, and Benjamin A. Olken. 2017. "The Development Effects of the Extractive Colonial Economy: The Dutch Cultivation System in Java." Working Paper.

Dimitrova-Grajzl, Valentina. 2007. "The Great Divide Revisited: Ottoman and Habsburg Legacies on Transition." Kyklos 60(4): 539-58.

Dohmen, Thomas, Armin Falk, David Huffman, and Uwe Sunde. 2012. "The Intergenerational Transmission of Risk and Trust Attitudes." Review of Economic Studies 79(2): 645-77.

Durante, Ruben. 2010. "Risk, Cooperation, and the Economic Origins of Social Trust: An Empirical Investigation." Working Paper.

Engerman, Stanley L. and Kenneth L. Sokoloff. 1997. "Factor Endowments, Institutions, and Differential Paths of Growth among New World Economies: A View from Economic Historians of the United States." In (S. Haber, ed.), How Latin America Fell Behind, pp. 260-304. Stanford, CA: Stanford University Press.

Enke, Benjamin. 2017. "Kinship Systems, Cooperation and the Evolution of Culture." NBER Working Paper 23499.

Fehr, Ernst, Urs Fischbacher, Bernhard von Rosenbladt, Jürgen Schupp, and Gert G. Wagner. 2002. "A Nation-Wide Laboratory - Examining Trust and Trustworthiness by Integrating Experiments in Representative Surveys." Schmollers Jahrbuch 122: 519-42.

Fershtman, Chaim, and Uri Gneezy. 2001. "Discrimination in a Segmented Society: An Experimental Approach." Quarterly Journal of Economics 116(1): 351-77.

Fisman, Raymond, and Tarun Khanna. 1999. "Is Trust a Historical Residue? Information Flows and Trust Levels." Journal of Economic Behavior and Organization 38(1): 79-92.

Gangadharan, Lata, Asadul Islam, Chandarany Ouch, and Liang Choon Wang. 2017. "The Long-term Effects of Genocide on Social Preferences and Risk." Working Paper.

Gershman, Boris. 2017. "Long-Run Development and the New Cultural Economics." In: Demographic Change and Long-Run Development, Matteo Cervelatti and Uwe Sunde (Eds.). Cambridge, MA: MIT Press, 221-61.

Giuliano, Paola. 2007. "Living Arrangements in Western Europe: Does Cultural Origin Matter?" Journal of the European Economic Association 5(5): 927-52.

Giuliano, Paola and Nathan Nunn. 2017. "Understanding Cultural Persistence and Change." Harvard Universtity, mimeo.

Glaeser, Edward L., David I. Laibson, José A. Scheinkman, and Christine L. Soutter. 2000. "Measuring Trust." Quarterly Journal of Economics 115(3): 811-46.

Gneezy, Uri, and Alex Imas. 2016. "Lab in the Field: Measuring Preferences in the Wild." In Handbook of Field Experiments, Abhijit Banerjee and Esther Duflo (Eds.). Volume 1 (439-64). North Holland: Elsevier.

Gorodnichenko, Yuriy, and Gérard Roland. 2017. "Culture, Institutions, and the Wealth of Nations." Review of Economics and Statistics 99(3): 402-16.

Greif, Avner. 1994. "Cultural Beliefs and the Organization of Society: A Historical and Theoretical Reflection on Collectivist and Individualist Societies." Journal of Political Economy 102(5): 912-50.

Greif, Avner. 2006. Institutions and the Path to the Modern Economy. Cambridge: Cambridge University Press. 
Greif, Avner, and Joel Mokyr. 2016. "Cognitive Rules, Institutions, and Economic Growth: Douglass North and Beyond." Journal of Institutional Economics 13(1): 25-52.

Greif, Avner, and Guido Tabellini. 2017. "The Clan and the Corporation: Sustaining Cooperation in China and Europe." Journal of Comparative Economics 45(1): 1-35.

Greif, Avner, and Steven Tadelis. 2010. "A Theory of Moral Persistence: Crypto-Morality and Political Legitimacy." Journal of Comparative Economics 38(3): 229-44.

Grosfeld, Irena, Alexander Rodnyansky, and Ekaterina Zhuravskaya. 2013. "Persistent Anti-market Culture: A Legacy of the Pale of Settlement and of the Holocaust." American Economic Journal: Economic Policy 5(3): $189-226$.

Grosfeld, Irena and Ekaterina Zhuravskaya. 2013. "Persistent Effects of Empires: Evidence from the Partitions of Poland." CEPR Discussion Paper 9371.

Grosjean, Pauline. 2011. "The Institutional Legacy of the Ottoman Empire: Islamic Rule and Financial Development in South Eastern Europe." Journal of Comparative Economics 39(1): 1-16.

Guiso, Luigi, Paola Sapienza, and Luigi Zingales. 2006. "Does Culture Affect Economic Outcomes?" Journal of Economic Perspectives 20(2): 23-48.

Guiso, Luigi, Paola Sapienza, and Luigi Zingales. 2008. "Social Capital as Good Culture." Journal of the European Economic Association 6(2-3): 295-320.

Guiso, Luigi, Paola Sapienza, and Luigi Zingales. 2016. "Long Term Persistence." Journal of the European Economic Association 14(6): 1401-36.

Henrich, Joseph, Robert Boyd, Samuel Bowles, Colin Camerer, Ernst Fehr, Herbert Gintis, and Richard McElreath. 2001. "In Search of Homo Economicus: Behavioral Experiments in 15 Small-Scale Societies." American Economic Review 91(2): 73-78.

Hooghe, Marc, Tim Reeskens, Dietlind Stolle, and Ann Trappers. 2009. "Ethnic Diversity and Generalized Trust in Europe: A Cross-National Multilevel Study." Comparative Political Studies 42(2): 198-223.

İnalcık, Halil. 1973. The Ottoman Empire. New York: Praeger.

Iyigun, Murat, and Jared Rubin. 2017. "The Ideological Roots of Institutional Change." Working Paper.

Jeon, Sangick, Tim Johnson, and Amanda Lea Robinson. 2017. "Nationalism and Social Sanctioning Across Ethnic Lines: Experimental Evidence from the KenyaTanzania Border." Journal of Experimental Political Science 4(1): 1-20.

Jha, Saumitra. 2013. "Trade, Institutions, and Ethnic Tolerance: Evidence from South Asia." American Political Science Review 107(4): 806-32.

Karaja, Elira. 2013. "The Rule of Karlowitz: Fiscal Change and Institutional Persistence." Working Paper.

Karlan, Dean S. 2005. "Using Experimental Economics to Measure Social Capital and Predict Financial Decisions." American Economic Review 95(5): 1688-99.

Karlan, Dean, Markus Mobius, Tanya Rosenblat, and Adam Szeidl. 2009. "Trust and Social Collateral." Quarterly Journal of Economics 124(3): 1307-61.

Kasara, Kimuli. 2013. "Separate and Suspicious: Local Social and Political Context and Ethnic Tolerance in Kenya." Journal of Politics 75(4): 921-36.

Kimbrough, Erik O., Vernon L. Smith, and Bart J. Wilson. 2008. "Historical Property Rights, Sociality, and the Emergence of Impersonal Exchange in Long-Distance Trade." American Economic Review 98(3): 1009-39. 
La Porta, Rafael, Florencio Lopez-de-Silanes, Andrei Shleifer, and Robert W. Vishny. 1998. "Law and Finance." Journal of Political Economy 106(6): 1113-55.

Lowes, Sara, Nathan Nunn, James A. Robinson, and Jonathan Weigel. 2017. "The Evolution of Culture and Institutions: Evidence from the Kuba Kingdom." Econometrica 85(4): 1065-91.

Marţolea, Ion. 1986. Udeşti, O Comunā din Ţara de Sus (Udeşti, a village from atop the lands). Translated by Lighthouse Translations. Bucharest.

Michalopoulos, Stelios and Elias Papaioannou. 2016. "The Long-Run Effects of the Scramble for Africa." American Economic Review 106(7): 1802-48.

Mokyr, Joel. 2016. A Culture of Growth: The Origins of the Modern Economy. Princeton: Princeton University Press.

Nannestad, Peter. 2008. "What Have We Learned About Generalized Trust, If Anything?" Annual Review of Political Science 11: 413-36.

North, Douglass C. 1990. Institutions, Institutional Change and Economic Performance. Cambridge: Cambridge University Press.

Nunn, Nathan. 2012. "Culture and the Historical Process." Economic History of Developing Regions 27(S1): $108-126$.

Nunn, Nathan, and Leonard Wantchekon. 2011. "The Slave Trade and the Origins of Mistrust in Africa." American Economic Review 101(7): 3221-52.

Putnam, Robert. 1993. Making Democracy Work: Civic Traditions in Modern Italy. Princeton: Princeton University Press.

Robinson, Amanda Lea. 2016. "Nationalism and Ethnic-Based Trust: Evidence From an African Border Region." Comparative Political Studies 49(14): 1819-54.

Roland, Gerard. 2017. "Culture, Institutions, and Development." Working paper.

Roland, Gerard, and David Y. Yang. 2017. "China's Lost Generation: Changes in Beliefs and their Intergenerational Transmission." Working paper.

Ruffle, Bradley J. and Richard Sosis. 2006. "Cooperation and the In-Group-Out-Group Bias: A Field Test on Israeli Kibbutz Members and City Residents." Journal of Economic Behavior and Organization 60(2): $147-63$.

Sapienza, Paola, Anna Toldra-Simats, and Luigi Zingales. 2013. "Understanding Trust." Economic Journal 123(573): 1313-32.

Spolaore, Enrico and Romain Wacziarg. 2013. "How Deep are the Roots of Economic Development?" Journal of Economic Literature 51(2): 325-69.

Subtelny, Orest. 2007. "The Habsburg and Russian Empires: Some Comparisons and Contrasts." In (H. Teruyuki and K. Matsuzato, eds.) Empire and Society: New Approaches to Russian History. Sapporo: Slavic Research Center, Hokkaido University, pp. 73-92

Sutter, Matthias and Martin G. Kocher. 2007. "Trust and Trustworthiness across Different Age Groups." Games and Economic Behavior 59(2): 364-82.

Tabellini, Guido. 2008a. "Institutions and Culture." Journal of the European Economic Association 6(2/3): $255-94$.

Tabellini, Guido. 2008b. "The Scope of Cooperation: Values and Incentives." Quarterly Journal of Economics 123(3): 905-50. 
Tabellini, Guido. 2010. "Culture and Institutions: Economic Development in the Regions of Europe." Journal of the European Economic Association 8(4): 677-716.

Tajfel, Henri, M. G. Billig, R. P. Bundy, and Claude Flament. 1971. "Social Categorization and Intergroup Behaviour." European Journal of Social Psychology 1(2): 149-78.

Tanis, Martin, and Tom Postmes. 2005. "A Social Identity Approach to Trust: Interpersonal Perception, Group Membership and Trusting Behaviour." European Journal of Social Psychology 35(3): 413-24.

Udişteanu, Arhimandrite Dionisie. 2005. Udeştii de pe Suceavă (Udeşti, A Village in Suceava). Translated by Lighthouse Translations. Suceava: Muşatinii.

Uslaner, Eric M., and Mitchell Brown. 2005. "Inequality, Trust, and Civic Engagement." American Politics Research 33(6): 868-94.

Voigtländer, Nico, and Hans-Joachim Voth. 2012. "Persecution Perpetuated: The Medieval Origins of AntiSemetic Violence in Nazi Germany." Quarterly Journal of Economics 127(3): 1339-92.

Wedeen, Lisa. 2002. "Conceptualizing Culture: Possibilities for Political Science." American Political Science Review 96(4): 713-28.

Whiteley, Paul F. 2000. "Economic Growth and Social Capital." Political Studies 48(3): 443-66.

Yuki, Masaki, William W. Maddux, Marilynn B. Brewer, and Kosuke Takemura. 2005. "Cross-Cultural Differences in Relationship- and Group-Based Trust." Personality and Social Psychology Bulletin 31(1): $48-62$.

Zak, Paul J. and Stephen Knack. 2001. "Trust and Growth." Economic Journal 111(470): 295-321. 


\section{A Appendix: Extra Tables and Robustness Checks \\ FOR ONLINE PUBLICATION}

Table A1: Summary Statistics, General Trust in Others and Public Goods

\begin{tabular}{|c|c|c|c|c|c|c|}
\hline Side of Border & $\begin{array}{l}\text { Can People } \\
\text { be Trusted }\end{array}$ & $\begin{array}{c}\text { Can People } \\
\text { be Trusted } \\
\text { (prior to } \\
1989 \text { ) }\end{array}$ & $\begin{array}{l}\text { Unofficial } \\
\text { Payment } \\
\text { to Police }\end{array}$ & $\begin{array}{l}\text { Unofficial } \\
\text { Payment } \\
\text { for Official } \\
\text { Documents }\end{array}$ & $\begin{array}{c}\text { Unofficial } \\
\text { Payment for } \\
\text { Education }\end{array}$ & $\begin{array}{l}\text { Unofficial } \\
\text { Payment for } \\
\text { Medical }\end{array}$ \\
\hline $\begin{array}{l}\text { Austrian } \\
\text { (Udeşti and Poieni) }\end{array}$ & $\begin{array}{c}0.65 \\
(0.03) \\
\mathrm{N}=267\end{array}$ & $\begin{array}{c}0.81 \\
(0.03) \\
\mathrm{N}=244\end{array}$ & $\begin{array}{c}0.13 \\
(0.02) \\
\mathrm{N}=269\end{array}$ & $\begin{array}{c}0.18 \\
(0.02) \\
\mathrm{N}=272\end{array}$ & $\begin{array}{c}0.24 \\
(0.03) \\
\mathrm{N}=270\end{array}$ & $\begin{array}{c}0.41 \\
(0.03) \\
\mathrm{N}=274\end{array}$ \\
\hline $\begin{array}{l}\text { Non-Austrian } \\
\text { (Ştirbăt) }\end{array}$ & $\begin{array}{c}0.66 \\
(0.05) \\
\mathrm{N}=89\end{array}$ & $\begin{array}{c}0.81 \\
(0.05) \\
\mathrm{N}=70\end{array}$ & $\begin{array}{c}0.13 \\
(0.03) \\
\mathrm{N}=95\end{array}$ & $\begin{array}{c}0.16 \\
(0.04) \\
\mathrm{N}=92\end{array}$ & $\begin{array}{c}0.19 \\
(0.04) \\
\mathrm{N}=89\end{array}$ & $\begin{array}{c}0.38 \\
(0.05) \\
\mathrm{N}=94\end{array}$ \\
\hline p-value: Diff in Means & 0.847 & 0.897 & 0.998 & 0.769 & 0.301 & 0.616 \\
\hline
\end{tabular}

Notes: Standard errors in parentheses. ${ }^{* *} p<0.01{ }^{*} p<0.05$. p-values from Wilcoxon rank-sum (Mann-Whitney) test. All variables take value of 1 if subject answered 3,4 , or 5 on 5 point scale.

Table A2: Summary Statistics, Personal Finance

\begin{tabular}{lccccc} 
Side of Border & $\begin{array}{c}\text { Have a Bank } \\
\text { Account }\end{array}$ & $\begin{array}{c}\text { Borrowed from } \\
\text { a Co-Villager }\end{array}$ & $\begin{array}{c}\text { Lent to a } \\
\text { Co-Villager }\end{array}$ & $\begin{array}{c}\text { Borrowed from } \\
\text { an Outsider }\end{array}$ & $\begin{array}{c}\text { Lent to } \\
\text { an Outsider }\end{array}$ \\
\hline $\begin{array}{c}\text { Austrian } \\
\text { (Udeşti and Poieni) }\end{array}$ & $\begin{array}{c}0.25 \\
(0.03)\end{array}$ & $\begin{array}{c}0.56 \\
(0.03)\end{array}$ & $\begin{array}{c}0.67 \\
(0.03)\end{array}$ & $\begin{array}{c}0.31 \\
(0.03)\end{array}$ & $\begin{array}{c}0.38 \\
(0.03)\end{array}$ \\
& $\mathrm{N}=291$ & $\mathrm{~N}=289$ & $\mathrm{~N}=295$ & $\mathrm{~N}=293$ & $\mathrm{~N}=290$ \\
$\begin{array}{c}\text { Non-Austrian } \\
\text { (Ştirbăt) }\end{array}$ & 0.28 & 0.71 & 0.77 & 0.38 & 0.46 \\
& $(0.05)$ & $(0.05)$ & $(0.04)$ & $(0.05)$ & $(0.05)$ \\
& $\mathrm{N}=92$ & $\mathrm{~N}=97$ & $\mathrm{~N}=98$ & $\mathrm{~N}=99$ & $\mathrm{~N}=97$ \\
p-value: Diff in Means & 0.545 & $0.009^{* *}$ & 0.070 & 0.203 & 0.159 \\
\hline
\end{tabular}

Notes: Standard errors in parentheses. ${ }^{* *} p<0.01{ }^{*} p<0.05$. p-values from Wilcoxon rank-sum (Mann-Whitney) test. 
Table A3: Summary Statistics, Experiment Results

\begin{tabular}{|c|c|c|c|c|c|c|}
\hline Side of Border & Question 1 & Question 2 & Question 3 & Question 4 & Question 5 & Question 6 \\
\hline $\begin{array}{l}\text { Austrian } \\
\text { (Udeşti and Poieni) }\end{array}$ & $\begin{array}{c}0.95 \\
(0.01) \\
\mathrm{N}=296\end{array}$ & $\begin{array}{c}0.82 \\
(0.02) \\
\mathrm{N}=291\end{array}$ & $\begin{array}{c}0.62 \\
(0.03) \\
\mathrm{N}=285\end{array}$ & $\begin{array}{c}0.77 \\
(0.02) \\
\mathrm{N}=284\end{array}$ & $\begin{array}{c}0.64 \\
(0.03) \\
\mathrm{N}=277\end{array}$ & $\begin{array}{c}0.68 \\
(0.03) \\
\mathrm{N}=270\end{array}$ \\
\hline $\begin{array}{l}\text { Non-Austrian } \\
\text { (Ştirbăt) }\end{array}$ & $\begin{array}{c}0.99 \\
(0.01) \\
\mathrm{N}=97\end{array}$ & $\begin{array}{c}0.95 \\
(0.02) \\
\mathrm{N}=95\end{array}$ & $\begin{array}{c}0.55 \\
(0.05) \\
\mathrm{N}=95\end{array}$ & $\begin{array}{c}0.82 \\
(0.04) \\
\mathrm{N}=93\end{array}$ & $\begin{array}{c}0.28 \\
(0.05) \\
\mathrm{N}=92\end{array}$ & $\begin{array}{c}0.44 \\
(0.05) \\
\mathrm{N}=86\end{array}$ \\
\hline p-value: Diff in Means & 0.099 & $0.003^{* *}$ & 0.227 & 0.351 & $0.000^{* *}$ & $0.001^{* *}$ \\
\hline Total Earnings (USD) & $\begin{array}{c}\text { Udeşti } \\
13.49 \\
(0.21) \\
\mathrm{N}=200\end{array}$ & $\begin{array}{c}\text { Poieni } \\
\\
18.21 \\
(0.35) \\
\mathrm{N}=100\end{array}$ & $\begin{array}{c}\text { Ştirbăt } \\
\begin{array}{c}18.34 \\
(0.35) \\
\mathrm{N}=100\end{array}\end{array}$ & & & \\
\hline
\end{tabular}

Notes: Standard errors in parentheses. ${ }^{* *} p<0.01 ;{ }^{*} p<0.05$. p-values from Wilcoxon rank-sum (Mann-Whitney) test. Earnings are lower in Udeşti (in part) because participants played two fewer rounds. p-value of difference in means between earnings in Poieni and Ştirbăt is 0.633. Earnings were paid in Romanian leu. The exchange rate at the time of the experiment was 4 leu: 1 USD.

Table A4: Average Amount Sent to Co-villagers and Outsiders, Treated data unpooled

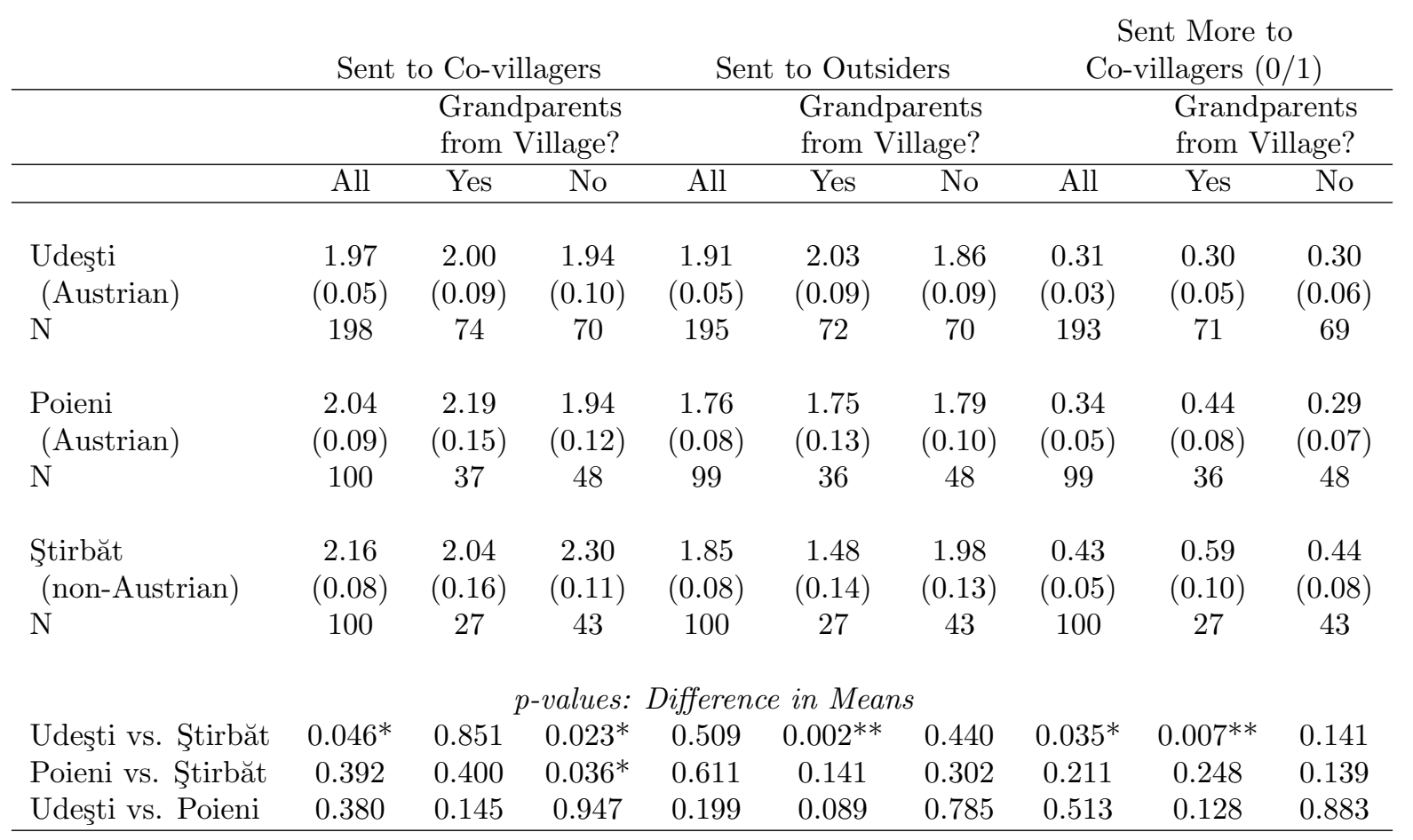

Notes: Standard errors in parentheses. ${ }^{* *} p<0.01{ }^{*} p<0.05$. p-values from Wilcoxon rank-sum (Mann-Whitney) test. Sent More to Home Village $=1$ if participant sent more to co-villagers than to outsiders. Outsiders are defined as the other village the participant played with in first four rounds. 
Table A5: Average Amount Sent to Co-villagers and Outsiders, Participants whose Great-Grandparents are and are not from the Village

\begin{tabular}{|c|c|c|c|c|}
\hline & \multirow{2}{*}{\multicolumn{2}{|c|}{$\begin{array}{c}\text { Sent to Co-villagers } \\
\text { Great-Grandparents } \\
\text { from Village? }\end{array}$}} & \multirow{2}{*}{\multicolumn{2}{|c|}{$\begin{array}{l}\text { Sent to Outsiders } \\
\text { Great-Grandparents }\end{array}$}} \\
\hline & & & & \\
\hline & Yes & No & Yes & No \\
\hline $\begin{array}{l}\text { Austrian } \\
\text { (Udeşti and Poieni) }\end{array}$ & $\begin{array}{c}2.09 \\
(0.09) \\
\mathrm{N}=87\end{array}$ & $\begin{array}{c}1.94 \\
(0.07) \\
\mathrm{N}=142\end{array}$ & $\begin{array}{c}1.96 \\
(0.08) \\
\mathrm{N}=83\end{array}$ & $\begin{array}{c}1.83 \\
(0.06) \\
\mathrm{N}=143\end{array}$ \\
\hline $\begin{array}{l}\text { Non-Austrian } \\
\text { (Ştirbăt) }\end{array}$ & $\begin{array}{c}1.95 \\
(0.18) \\
\mathrm{N}=22\end{array}$ & $\begin{array}{c}2.31 \\
(0.11) \\
\mathrm{N}=48\end{array}$ & $\begin{array}{c}1.50 \\
(0.16) \\
\mathrm{N}=22\end{array}$ & $\begin{array}{c}1.92 \\
(0.12) \\
\mathrm{N}=48\end{array}$ \\
\hline p-value: Diff in Means & 0.443 & $0.008^{* *}$ & $0.008^{* *}$ & 0.497 \\
\hline
\end{tabular}

Notes: Standard errors in parentheses. ${ }^{* *} p<0.01{ }^{*} p<0.05$. p-values from Wilcoxon rank-sum (Mann-Whitney) test. Outsiders are defined as the other village the participant played with in first four rounds

Table A6: Ordered Probit Regressions: Average Amount Sent to Co-villagers and Outsiders, with potentially endogenous regressors

\begin{tabular}{|c|c|c|c|c|}
\hline Dependent Variable: & Sent to & -villagers & Sent to & utsiders \\
\hline Ştirbăt Dummy & $\begin{array}{c}0.31 \\
(0.16)\end{array}$ & $\begin{array}{l}0.56^{*} \\
(0.23)\end{array}$ & $\begin{array}{c}0.08 \\
(0.16)\end{array}$ & $\begin{array}{c}0.28 \\
(0.23)\end{array}$ \\
\hline Grandparents from & & 0.04 & & 0.01 \\
\hline Village Dummy & & $(0.17)$ & & $(0.17)$ \\
\hline Grandparents from & & -0.49 & & $-0.74^{*}$ \\
\hline Village * Ştirbăt & & $(0.38)$ & & $(0.37)$ \\
\hline Order: Own First & $\begin{array}{l}-0.16 \\
(0.15)\end{array}$ & $\begin{array}{l}-0.10 \\
(0.17)\end{array}$ & $\begin{array}{c}-0.46^{* *} \\
(0.15)\end{array}$ & $\begin{array}{l}-0.33 \\
(0.17)\end{array}$ \\
\hline Know Someone & 0.21 & 0.14 & 0.05 & 0.09 \\
\hline From Other Village & $(0.17)$ & $(0.19)$ & $(0.17)$ & $(0.18)$ \\
\hline $\mathrm{N}$ & 293 & 237 & 289 & 233 \\
\hline Pseudo R-squared & 0.05 & 0.06 & 0.05 & 0.05 \\
\hline QUIZ SCORE & YES & YES & YES & YES \\
\hline DEMOGRAPHIC & YES & YES & YES & YES \\
\hline FINANCE & YES & YES & YES & YES \\
\hline PAY FOR SERVICE & YES & YES & YES & YES \\
\hline
\end{tabular}

Notes: Standard errors in parentheses. ${ }^{* *} p<0.01{ }^{*} p<0.05$. Quiz Score is number correct out of 6 on incentivized quiz. Demographic characteristics are a gender dummy, age, age squared, married dummy, high school education dummy, Eastern Orthodox dummy, dummy for whether subjects attend religious services, and dummies for occupation type (not employed, blue collar, agriculture, service, and other). Finance includes dummies for whether one has borrowed and lent to co-villagers and outsiders. Pay for Service is an answer (1-5) regarding how often one has to pay bribes to police, for official documents, to receive public education, and to receive medical treatment. 
Table A7: Average Amount Returned to Co-villagers and Outsiders, Participants whose Great-Grandparents are and are not from the Village

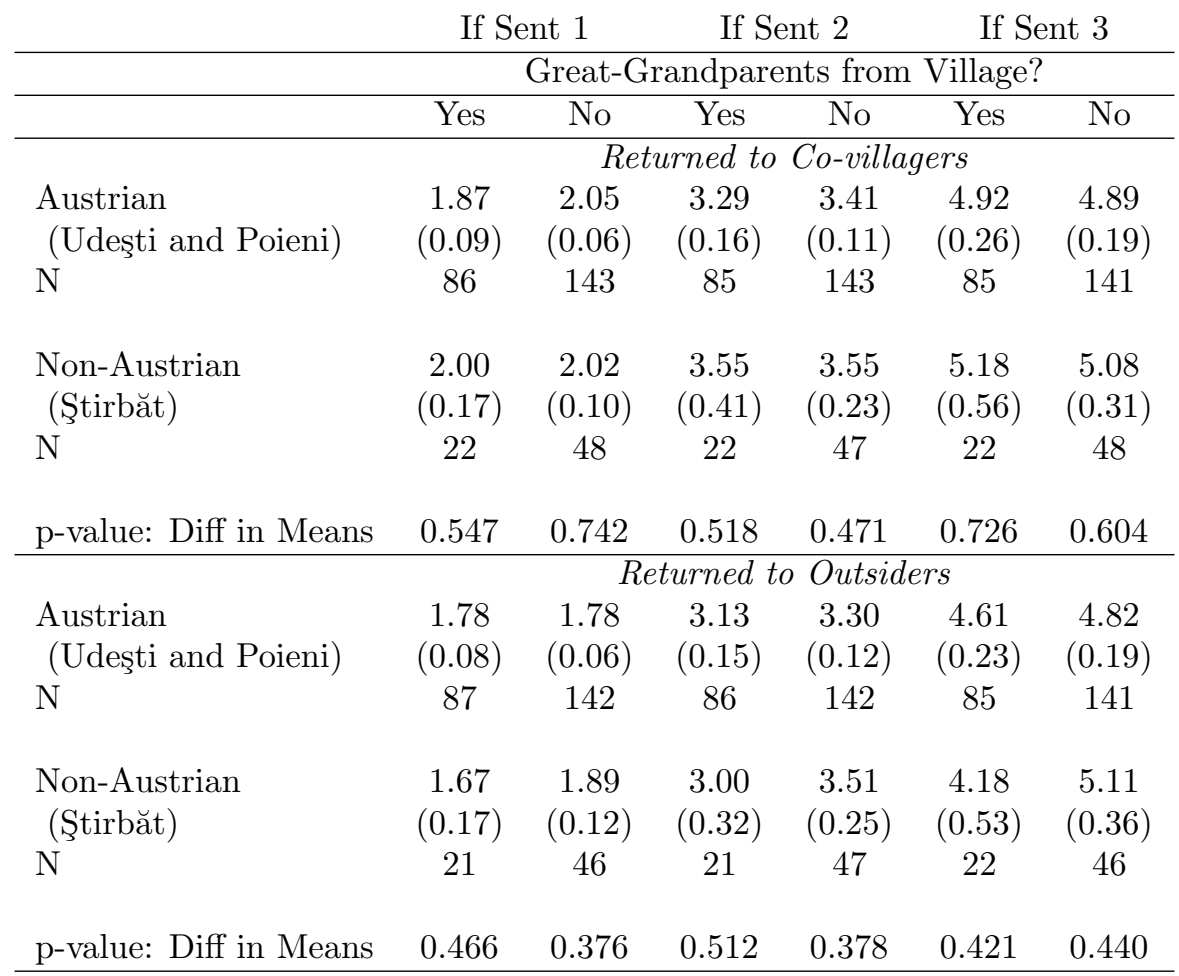

Notes: Standard errors in parentheses. ${ }^{* *} p<0.01{ }^{*} p<0.05$. p-values from Wilcoxon rank-sum (Mann-Whitney) test. 


\section{B Appendix: Sample Instructions (in English) $)^{36}$ \\ FOR ONLINE PUBLICATION}

\section{B.1 Instructions: Send Decision}

This is an experiment in the economics of decision-making conducted by Cult Research on behalf of researchers in the USA. The instructions are simple.

You will receive 10 lei simply for participating in the experiment. If you follow the instructions carefully, you have the potential to earn a significant amount more. A Cult Research employee will collect your decisions from the experiment, and a different Cult Research employee will calculate how much you earned during the experiment. In one week, the Cult Research employee will return and pay you the amount you earned during the experiment. Please note that if you talk to others during the experiment or exclaim out loud, you will be asked to leave and you will not be paid.

There are 200 participants taking place in the experiment from Udeşti. You will not be told the names of the other participants and they will not be told your name. All participants have identical instructions.

\section{The Decision Situation}

You will begin the experiment with 3 tokens. Each token is equivalent to $\mathbf{3}$ lei, meaning that you start the experiment with 9 total lei.

You will be partnered with another participant from Udeşti. You will not know who you are partnered with when you make your decisions, and you will not find out who you were partnered with after the experiment is over. We will call this person your "partner" for the remainder of these instructions.

\section{Your Decision}

The Cult Research employee will give you a handout after the instructions are read. At the top of the handout are numbers from 0 to 3 .

You will circle one - and only one - of these numbers. The number you circle is the amount of your 3 tokens you will send to the participant from Udeşti with whom you are matched. You can choose any number you like, but you can only choose one number. You will keep any tokens you do not send to your partner.

\section{Transferring Tokens to Your Partner}

Your partner will receive $\mathbf{3}$ times the number of tokens you circled on your handout.

For example, if you choose 2 tokens, your partner will receive 6 tokens. If you choose 0 tokens, your partner will receive 0 tokens. If you choose 3 tokens, your partner will receive 9 tokens.

The following table indicates how many tokens your partner receives for each possible amount you might circle.

\footnotetext{
${ }^{36}$ These instructions were the ones given to the participants in Udeşti when they played with other participants in Udeşti (in the order in which one played against their own village first). Instructions for the other villages were exactly the same, with only the names of the villages changed. Instructions for later rounds were similar but abbreviated.
} 


\begin{tabular}{cc}
$\begin{array}{c}\text { Amount you } \\
\text { circle }\end{array}$ & $\begin{array}{c}\text { Your partner } \\
\text { receives }\end{array}$ \\
\hline 0 & 0 \\
1 & 3 \\
2 & 6 \\
3 & 9
\end{tabular}

\section{Your Partner's Decision}

Your partner will have the opportunity to return all, some, or none of the tokens you send them. They can choose to return to you anywhere between 0 tokens and the number of tokens they receive.

For example, if you choose to send your partner 2 tokens, your partner will receive 6 tokens. This means that they can choose to return to you $0,1,2,3,4,5$, or 6 tokens.

For another example, if you choose to send your partner 1 token, your partner will receive 3 tokens. This means that they can choose to return to you $0,1,2$, or 3 tokens.

Your partner will not know how many tokens you sent them when they make their decision. Instead, they will fill out the following table. This table indicates how many tokens they will return to you for each possible number of tokens they received. Your partner will circle one number in each of the lower 3 boxes. We have circled the 0 in the first box, because if you send zero, your partner has no choice but to return 0 to you.

\begin{tabular}{|c|c|c|c|c|c|c|c|c|c|c|c|}
\hline $\begin{array}{c}\text { If your } \\
\text { partner sends }\end{array}$ & $\begin{array}{l}\text { You } \\
\text { eceive }\end{array}$ & & $\mathrm{ircl}$ & a $n$ & $\mathrm{mb}$ & to & tur & to & $\mathrm{urr}_{3}$ & $\operatorname{arn}$ & \\
\hline 0 & 0 & ) & & & & & & & & & \\
\hline 1 & 3 & 0 & 1 & 2 & 3 & & & & & & \\
\hline 2 & 6 & 0 & 1 & 2 & 3 & 4 & 5 & 6 & & & \\
\hline 3 & 9 & 0 & 1 & 2 & 3 & 4 & 5 & 6 & 7 & 8 & 9 \\
\hline
\end{tabular}

\section{End of the Experiment}

After the experiment is over, we will look at how many tokens you sent to your partner. We will take that amount and see what your partner says he/she would return to you should you send the amount you indicated.

For example, say you choose to send 2 tokens to your partner. This is multiplied by 3 , so your partner has 6 tokens. We then look to see how many tokens your partner chooses to return to you when you chose to send him/her 2 tokens. 


\section{You and Your Partner's Income}

You will keep each token you do not send to your partner. Your will also keep all tokens that your partner returns to you. At the end of the experiment, each token will be converted to 3 lei and paid to you in cash in one week.

Your Total Income $=$ Tokens you do not send to your partner $(=3$ tokens - amount you send $)+$ Amount returned to you by your partner

Your Partner's Total Income $=3^{*}$ Tokens you send - amount your partner returns to you

\section{Examples}

EXAMPLE 1: Suppose that you decide to send 1 token to your partner. This 1 token is multiplied by 3 , meaning that your partner receives 3 tokens. Suppose that in the box next to 1, your partner circles 2, meaning that she will return 2 tokens to you and keep 1 token. Your total earnings are therefore $(3-1)+$ $2=4$ tokens. Your partner's earnings are $3-2=1$ token.

EXAMPLE 2: Suppose that you decide to send 3 tokens to your partner. These 3 tokens are multiplied by 3 , meaning that your partner receives 9 tokens. Suppose that in the box next to 3, your partner chooses 2, meaning that she will return 2 tokens to you and keep 7 tokens. Your total earnings are therefore $(3-3)+$ $2=2$ tokens. Your partner's earnings are $9-2=7$ tokens.

The Cult Research employee will now hand out a short quiz to test your understanding of the experiment.

\section{Playing the Game}

You have been randomly matched with a participant from Udeşti. You will play this game only once. Please circle one (and only one) number on the handout that the Cult Research employee will hand to you shortly. At the end of the experiment, we will convert each of your tokens into 3 lei.

\section{B.2 Instructions: Return Decision}

You will now participate in the same experiment you just participated in, except now your role will be reversed. Like before, there are 200 participants taking place in the experiment from Udeşti. You will not be told the names of the other participants and they will not be told your name. All participants have identical instructions. You will not be matched with the same person you were matched with in the previous experiment. We will briefly refresh you on the decision situation below.

\section{The Decision Situation}

You will begin the experiment with 0 tokens. Each token is equivalent to 3 lei, meaning that you start the experiment with 0 total lei. You will be matched with another participant from Udeşti.

Tokens sent to you by your partner are multiplied by three. You will then be given the opportunity to return none, some, or all of the tokens your partner sent to you. You will keep any tokens you do not return to your partner.

\section{Your Decision}


Your partner will circle the amount he/she will send to you. They can circle any number between 0 and 3 .

You will receive 3 times the number of tokens your partner circled on his/her handout. You will not know how many tokens your partner from Udeşti sent to you when you make your decision. Instead, you will fill out the following table. This table indicates how many tokens you will return to your partner for each possible number of tokens they sent you. You will circle one number in each of the last 3 boxes. Please note that we have already circled "0" next to the top box because that is your only option. You do not need to circle anything in this box.

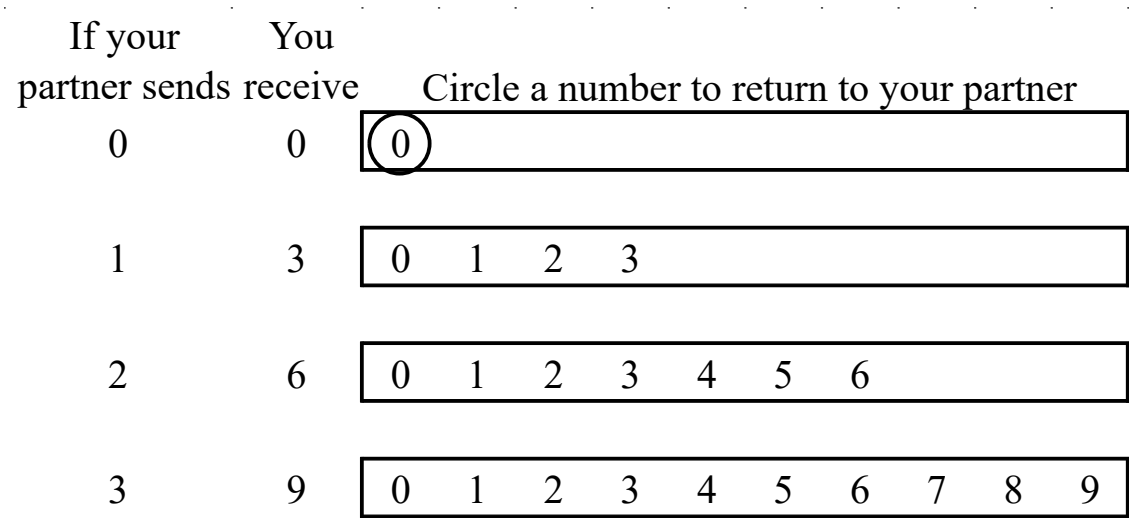

You and Your Partner's Income

You will keep each token you do not return to your partner. At the end of the experiment, each token will be converted to 3 lei and paid to you in cash in one week.

Your Total Income $=3^{*}$ Tokens your partner sends - amount you return to your partner

Your Partner's Total Income $=$ Tokens he/she does not send to you $(=3$ tokens - amount he $/$ she sends $)+$ Amount you return to him/her

\section{Playing the Game}

You have been randomly matched with a participant from Udeşti. You will play this game only once. Please circle one (and only one) number in each of the three bottom boxes on the handout that the Cult Research employee will hand to you shortly (you do not need to circle a number in the first box; we have already circled 0 for you). At the end of the experiment, we will convert each of your tokens into 3 lei.

\section{B.3 Quiz}

The 6 questions below will test your understanding of the experiment. You will be paid $\mathbf{0 . 7 5}$ leu for each question you answer correctly. You will not be paid for incorrect answers. Please write your answer on the line provided next to each question. If we cannot read your answers, they will be counted as incorrect.

The Situation: Suppose that you decide to send $\mathbf{2}$ tokens to your partner by circling the 2 on your handout as follows: 


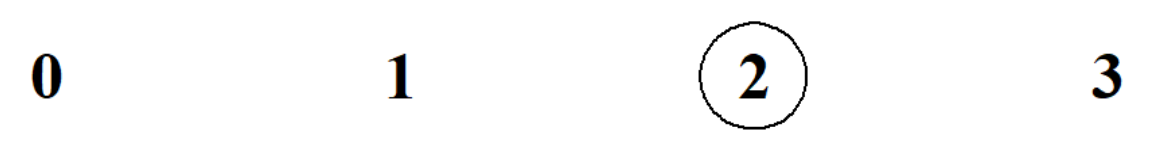

Suppose that the participant with whom you are randomly matched (your partner) fills out their handout as on the following page.

Question 1: How many tokens will your partner return to you?

Question 2: How many total tokens will you earn?

Question 3: How many total tokens will your partner earn?

Now, instead of assuming that you chose to send 2 tokens to your partner, assume that you chose to send 3 tokens. Please answer the following questions, assuming that your partner fills out their handout as on the following page.

Question 4: How many tokens will your partner return to you?

Question 5: How many total tokens will you earn?

Question 6: How many total tokens will your partner earn?

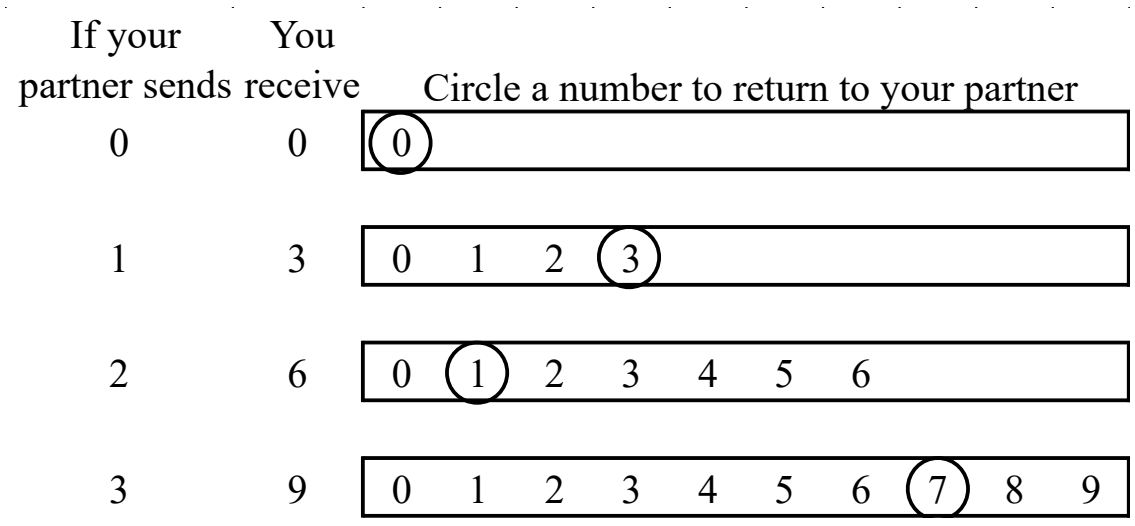

\section{B.4 Survey ${ }^{37}$}

Please fill out this brief survey by circling the answer that most accurately applies. If there is a line next to a question, please enter your answer on the line. Your entries are confidential: none of the information in this survey will ever be matched to your name or shared with anybody outside of those conducting the experiment.

1) What is your gender?

a. Male

b. Female

2) What is your age?

37 This sample survey is the one given to participants in Udeşti. Participants in Poieni and Ştirbăt received surveys with different questions 23, 24, and 25, since they played against participants from both villages. Questions 5-7 were re-worded in Poieni and Ştirbăt to reflect their home village, while questions 19-22 were re-worded to reflect the other two villages. 
3) What is your marital status?
a. Single
b. Married
c. Divorced
d. Widowed
e. Other

4) What is the highest level of education you completed?
a. None, or lower than grade school
b. Grade school or Middle school
c. High school
d. College (undergraduate)
e. College (graduate)

5) Have you lived in Udeşti your entire life?
a. Yes
b. No

6) If you answered "No" to Question 5, how long have you lived in Udeşti?

7) To your knowledge, how long has your family lived in Udeşti?
a. $\quad$ You moved to Udeşti during your lifetime
b. Your parents moved to Udeşti
c. Your grandparents moved to Udeşti
d. Your great-grandparents or an older generation moved to Udeşti
e. I don't know

8) What is your occupation?

9) What is your religion?
a. Eastern Orthodox
b. Roman Catholic
c. None/non-religious
d. Other (please list)

10) How often do you attend religious services?
a. Never
b. Once or twice a year (or less)
c. Several times a year
d. Once a month
e. $\quad 2-3$ times a month
f. Weekly
g. Several times a week

11) Generally speaking, would you say that most people can be trusted, or that you can't be too careful in dealing with people? Please answer on a scale from 1 to 5 , where 1 means that you have complete distrust in people, and 5 means that most people can be trusted.

a. What would it be today? (please answer 1 through 5 )

b. And before 1989? (please answer 1 through 5)

12) In your opinion, how often is it necessary for people like you to have to make unofficial payments/gifts in these situations? Please answer on a scale from 1 to 5, where the scale is as follows: (Scale: Never=1, Seldom $=2$, Sometimes $=3$, Usually $=4$, Always $=5$ )

a. Interact with road police (please answer 1 through 5 ) 
b. Dealing with official documents (1 through 5$)$

c. Receive public education (1 through 5$)$

d. Receive medical treatment (1 through 5$)$

13) Do you have a bank account?

a. Yes

b. No

14) Have you ever borrowed money from someone living in Udeşti?

a. Yes

15) Have you ever lent money to someone living in Udeşti?

a. Yes

b. No

16) Have you ever borrowed money from someone living outside of Udeşti?

a. Yes

17) Have you ever lent money to someone living outside of Udeşti?

a. Yes

b. No

18) How trustworthy, in general, do you think the people of Udeşti are?

a. Extremely trustworthy

b. Somewhat trustworthy

c. Uncertain

d. Somewhat untrustworthy

e. Extremely untrustworthy

19) Do you know anybody from Ştirbăt?

a. Yes

b. No

20) How trustworthy, in general, do you think the people of Ştirbăt are?

a. Extremely trustworthy

b. Somewhat trustworthy

c. Uncertain

d. Somewhat untrustworthy

e. Extremely untrustworthy

21) Do you know anybody from Poieni?

a. Yes

b. No

22) How trustworthy, in general, do you think the people of Poieni are?
a. Extremely trustworthy
b. Somewhat trustworthy
c. Uncertain
d. Somewhat untrustworthy
e. Extremely untrustworthy

23) Did you make choices differently when your partner was from Udeşti than when they were from Ştirbăt? 
a. Yes

24) If you answered "Yes" to Question 23, why did you make your choices differently? Please answer below, and use as much space as needed. 


\section{Appendix: Sample Instructions (in Romanian) $)^{38}$ \\ FOR ONLINE PUBLICATION}

\section{C.1 Instructions: Send Decision}

Aceasta este un studiu cu caracter economic despre luarea deciziilor. Acesta este condus de Cult Research din partea cercetătorilor din Statele Unite ale Americii. Instrucţiunile sunt simple.

Veţi primi 10 lei doar pentru simpla participare la experiment. Dacă veţi urmări instrucţiunile cu atenţie, aveţi posibilitatea să câştigaţi o sumă mai mare de bani. Unul dintre angajaţii Cult Research va colecta deciziile dumneavoastră cu privire la experiment, iar un alt angajat de la Cult Research va calcula cât de mult aţi câştigat de-a lungul experimentului. Într-o săptămână, reprezentantul Cult Research se va întoarce şi vă va oferi suma de bani pe care aţi acumulat-o de-a lungul experimentului. Vă rugăm să fiţi atenţi la faptul că dacă veţi vorbi cu ceilalţi în timpul experimentului sau dacă vă veţi exprima cu voce tare, veţi fi rugat să părăsiţi încăperea şi nu veţi fi plătit.

Vor fi un număr de participanţi care participă la experiment din localitatea Udeşti. Nu le veţi spune numele dumneavoastră celorlalţi participanţi la studiu şi ei nu vă vor spune numele lor. Toţi participanţii vor avea instrucţiuni identice.

\section{Situaţia de decizie}

Veţi începe experimentul cu 3 jetoane. Fiecare jeton este echivalent cu 3 lei, acest lucru însemnând că veţi incepe experimentul cu un total de 9 lei.

Veţi fi pus în legătură cu un alt participant din localitatea Udeşti. Nu veţi şti cu cine aţi fost pus în legătură atunci când luaţi deciziile şi nici nu veţi şti cu cine aţi fost pun în legătură odată ce experimentul s-a încheiat. Îi vom spune acestei persoane că este "partenerul" dumneavoastră pentru restul acestor instrucţiuni.

\section{Decizia dumneavoastră}

Un angajat Cult Research vă va înmâna un suport de hârtie după ce instrucţiunile au fost citite. În partea de sus a acestuia sunt numere de la 0 la 3 .

Va trebui să încercuiţi unul - şi doar unul - dintre aceste numere. Numărul pe care îl încercuiţi reprezintă câte din cele 3 jetoane pe care le aveţi decideţi să i le trimiteţi participantului din Udeşti cu care dumneavoastră sunteţi pus în legătură. Puteţi alege orice număr doriţi, dar să fiţi atenţi să fie doar un singur număr. Veţi păstra orice jeton pe care nu îl veţi trimite partenerului dumneavoastră.

\section{Transferul de jetoane către partenerul dumneavoastră}

Partenerul dumneavoastră va primi de 3 ori mai multe jetoane decât aţi încercuit pe suportul de hârtie.

De exemplu, dacă alegeţi 2 jetoane, partenerul dumneavoastră va primi 6 jetoane. Dacă alegeţi 0 jetoane, partenerul dumneavoastră va primi 0 jetoane. Dacă alegeţi 3 jetoane, partenerul dumneavoastră va primi 9 de jetoane.

Tabelul alăturat indică numărul de jetoane pe care îl poate primi partenerul dumneavoastră pentru fiecare sumă pe care dumneavoastră o încercuiţ̧i. 


\begin{tabular}{cc}
$\begin{array}{c}\text { Cât încercuiţi } \\
\text { dumneavoastră }\end{array}$ & $\begin{array}{c}\text { Cât primeşte } \\
\text { partenerul } \\
\text { dumneavoastră }\end{array}$ \\
\hline 0 & 0 \\
1 & 3 \\
2 & 6 \\
3 & 9
\end{tabular}

Decizia partenerului dumneavoastră

Partenerul dumneavoastră are oportunitatea să returneze tot, o parte sau niciunul dintre jetoanele pe care dumneavoastră i le-aţi trimis. El are opţiunea să returneze orice număr de jetoane cuprins între zero şi numărul de jetoane pe care îl primesc.

De exemplu, dacă alegeţi să îi trimiteţi partenerului dumneavoastră 2 jetoane, acesta va primi 6 jetoane. Acest lucru înseamnă că el poate alege să vă returneze $0,1,2,3,4,5$ sau 6 jetoane.

Un alt exemplu: dacă dumneavoastră alegeţi să îi trimiteţi partenerului dumneavoastră 1 jeton, acesta va primi 3 jetoane. Acest lucru înseamnă că el poate alege să vă returneze $0,1,2$ sau 3 jetoane.

Partenerul dumneavoastră nu va şti câte jetoane i-aţi trimis atunci când va lua propria decizie. În schimb, el va completa tabelul următor. Acest tabel arată câte jetoane vă va returna pentru fiecare număr posibil de jetoane pe care îl primeşte. Partenerul dumneavoastră va încercui un număr în fiecare din cele 3 căsuţe. Am încercuit noi deja 0 pentru dumneavoastră în prima căsuţă, deoarece dacă trimiteţi zero, partenerul dumneavoastră nu are nici o opţiune de returnare, în afară de zero.

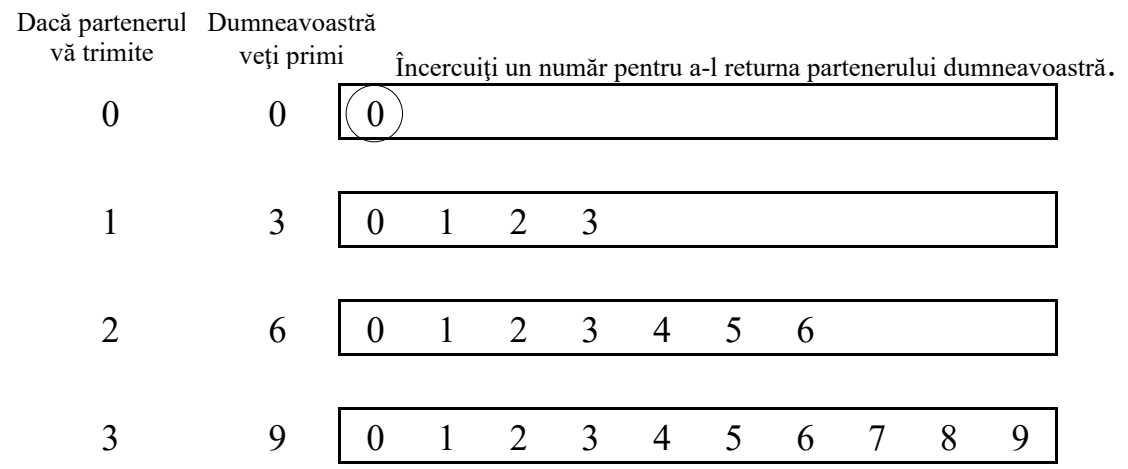

Sfârşitul acestui experiment

După ce experimentul se încheie, ne vom uita la câte jetoane aţi trimis partenerului. Vom lua acea sumă şi vom vedea ce vă va returna partenerul dumneavoastră atunci când dumneavoastră îi trimiteţi suma indicată.

${ }_{38}^{38}$ As in Appendix B, we only provide instructions for the send and return decisions of the paricipants from Udeşti when they played with other participants from Udeşti. Instructions for Poieni and Ştirbăt were the same, with the name of the villages changed. 
De exemplu, să spunem că alegeţi să trimiteţi 2 jetoane partenerului dumneavoastră. Acestea se înmulţesc cu trei, astfel partenerului dumneavoastră îi revine 6 jetoane. Atunci, ne vom uita la câte jetoane alege partenerul dumneavoastră să vă returneze atunci când dumneavoastră alegeţi să îi trimiteţi 2 jetoane.

\section{Venitul dumneavoastră şi al partenerului}

Veţi păstra fiecare jeton pe care alegeţi să nu îl trimiteţi partenerului. De asemenea, veţi păstra toate jetoanele pe care vi le returnează partenerul. La sfârşitul experimentului, fiecare jeton va fi convertit într-un leu, iar plata se va face într-o săptămână.

Venitul dumneavoastră total = Jetoanele pe care nu le-aţi trimis partenerului dumneavoastră (=3 jetoane - suma pe care o trimite Participantul 1) + Suma returnată de partenerul dumneavoastră.

Venitul total al partenerului dumneavoastră $=3^{*}$ jetoanele pe care i le-aţi trimis - suma pe care partenerul decide să v-o returneze.

\section{Examples}

EXEMPLUL 1: Să presupunem că dumneavoastră decideţi să trimiteţi 1 jeton partenerului dumneavoastră. Acest jeton va fi înmulţit cu 3 , ceea ce înseamnă că partenerul dumneavoastră va primi 3 jetoane. Să presupunem că în căsuţa alăturată numărului 1 , partenerul dumneavoastră va încercui 2 , ceea ce înseamnă că acesta va returna 2 jetoane şi va păstra 1 jeton. Câş̧tigul total al dumneavoastră este $(3-1)+2=4$

jetoane. Partenerul dumneavoastră are un câştig de $3-2=1$ jeton.

EXEMPLUL 2: Să presupunem că dumneavoastră decideţi să trimiteţi 3 jetoane Participantului 2. Aceste 3 jetoane sunt înmulţite cu 3, ceea ce înseamnă că Participantul 2 va primi 9 de jetoane. Să presupunem că în căsuţa alăturată numărului 3 , partenerul dumneavoastră va scrie 2 , ceea ce înseamnă că acesta vă va returna 2 jetoane şi va păstra 7 jetoane. Câştigul dumneavoastră total este de $(3-3)+2=2$ jetoane. Partenerul dumneavoastră are un câştig de $9-2=7$ jetoane.

Un reprezentant Cult Research vă va înmâna un scurt test pentru a verifica dacă dumneavoastră aţi înţeles cerinţele experimentului.

\section{Desfăşurarea jocului}

Aţi fost pus în legătură în mod aleatoriu cu un participant la studiu din Udeşti. Vă veţi juca acest joc o singură dată. Vă rugăm să încercuiţi un singur număr pe suportul de hârtie pe care vi-l va înmâna un angajat de la Cult Research în scurt timp. La sfârşitul experimentului, vă vom converti fiecare jeton pe care îl aveţi în 3 lei.

\section{C.2 Instructions: Return Decision}

Acum veţi participa la acelaşi experiment la care tocmai aţi participat, cu excepţia că rolul dumneavoastră va fi inversat. La fel ca înainte, vor participa la experiment un număr de persoane din Udeşti. Nu vi se vor spune numele celorlalţi participanţi şi nici dumneavoastră nu veţi spune celorlalţi numele dumneavoastră. Toţi participanţii vor avea aceleaşi instrucţiuni. Nu veţi fi pus în legătură cu aceeaşi persoană cu care aţi corespondat în cadrul experimentului anterior. O să vă reamintim pe scurt în ce constă situaţia de decizie.

\section{Situaţia de decizie}


Veţi începe experimentul cu 0 jetoane. Fiecare jeton este echivalentul a $\mathbf{3}$ lei, ceea ce înseamnă că veţi începe experimentul cu un total de 0 lei. Veţi fi pus în legătură cu un alt participant din Udeşti.

Jetoanele trimise de partenerul dumneavoastră vor fi multiplicate de trei ori. Veţi putea returna zero, câteva sau toate jetoanele primite de la partenerul dumneavoastră. Veţi păstra jetoanele pe care nu le-aţi trimis partenerului.

\section{Decizia dumneavoastră}

Partenerul dumneavoastră va încercui suma pe care el/ea decid să v-o trimită. El poate încercui orice număr cuprins între 0 şi 3 .

Veţi primi de 3 ori numărul jetoanelor pe care partenerul dumneavoastră îl încercuieşte în materialul lui printat. Nu veţi şti câte jetoane aţi primit de la partenerul dumneavoastră din Udeşti atunci când veţi lua decizia. În schimb, veţi completa următorul tabel. Acest tabel arată câte jetoane se vor întoarce la partenerul dumneavoastră pentru fiecare număr posibil de jetoane pe care acesta vi-l va trimite. Veţi încercui un număr în fiecare dintre cele 3 căsuțe. Vă rugăm să fiți atenți la faptul că am încercuit deja 0 , deoarece aceasta este singura dumneavoastră opţiune. Nu va fi nevoie să încercuiţi altceva în această căsuţă.

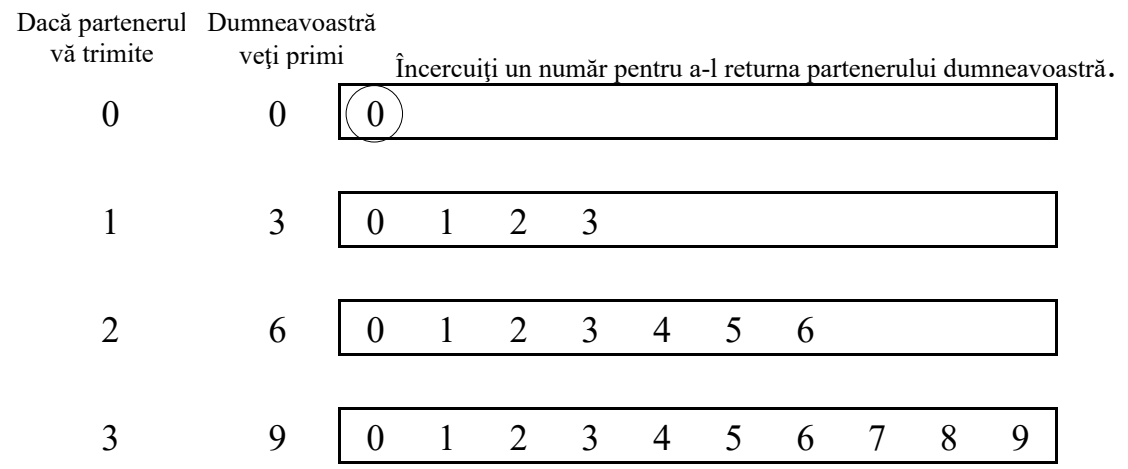

\section{Venitul dumneavoastră şi cel al partenerului}

Veţi păstra fiecare jeton pe care nu îl veţi returna partenerului dumneavoastră. La sfârşitul experimentului fiecare jeton va fi convertit în 3 lei şi veţi fi plătit în numerar într-o săptămână.

Venitul dumneavoastră total $=3 *$ jetoanele pe care vi le trimite partenerul - suma pe care o returnaţi partenerului.

Venitul total al partenerului dumneavoastră $=$ jetoanele pe care acesta nu vi le trimite $(=3$ jetoane - suma pe care nu v-o trimite) + suma pe care dumneavoastră o returnaţi.

\section{Desfăşurarea jocului}

Aţi fost pus în legătură în mod aleator cu un participant din Udeşti. Vă veţi juca acest joc o singură dată. Vă rugăm să încercuiţi un singur număr în fiecare căsuţă din materialul printat pe care vi l-a înmânat unul dintre reprezentanţii Cult Research (nu va trebui să încercuiţi un număr în prima căsuţă; am încercuit noi deja 0 pentru dumneavoastră). La sfârşitul experimentului vom converti fiecare jeton în 3 lei. 